\title{
Thomas Wylton's Question "An contingit dare ultimum rei permanentis in esse"
}

\section{CECILIA TRIFOGLI}

In his Questions on Aristotle's Physics 8,1 Thomas Wylton deals extensively with the problem of assigning temporal limits to the existence of permanent things, as, for instance, of fire, of water, and of a substance's being hot. Wylton's discussion of this problem is incorporated into the question "An contingit dare ultimum rei permanentis in esse," which represents his major contribution to that large body of medieval literature concerning the so-called de primo et ultimo instanti or de incipit et desinit problem or, more synthetically, the limit decision problem. ${ }^{2}$

1. Thomas Wylton was Fellow of Merton College in the last decade of the thirteenth century and during the first years of the fourteenth. He was Magister Artium in Oxford probably until 1304. In the second decade of the fourteenth century he was Magister Theologiae in Paris. The Quaestiones libri Physicorum constitute his main extant work in natural philosophy. Although this work has not yet been dated, it is very likely to have been written before the 1304-1305 school year, that is, when Wylton was still Magister Artium in Oxford. For the bibliography on Wylton's biography and works, see Trifogli, "Il problema dello statuto ontologico del tempo nelle Quaestiones super Physicam di Thomas Wylton e di Giovanni di Jandun," Documenti e studi sulla tradizione filosofica medievale 1 (1990): 491-495.

2. In using the expression "limit decision problem," I follow Murdoch and Knuuttila. See John E. Murdoch, "Propositional Analysis in Fourteenth-Century Natural 
Since the publication in 1956 of Curtis Wilson's pioneering work William Heytesbury: Medieval Logic and the Rise of Mathematical Physics, ${ }^{3}$ this problem area has been capturing increasing interest among historians of medieval philosophy and logic. They have pointed out that in thirteenth-and fourteenth-century discussions of the limit decision problem some of the most original aspects of the medieval treatment of Aristotle's theory of continuity are to be found. ${ }^{4}$ Although some representative medieval texts have been edited since then, ${ }^{5}$ most source material is not yet available.

In this essay I shall provide a critical edition of Thomas Wylton's question "An contingit dare ultimum rei permanentis in esse." As an

Philosophy: A Case Study," Synthese 40 (1979): 117-146; Simo Knuuttila, "Remarks on the Background of the Fourteenth Century Limit Decision Controversies," in The Editing of Theological and Philosophical Texts from the Middle Ages, ed. Monika Asztalos, Acta Universitatis Stockholmiensis, Studia Latina Stockholmiensia 30 (Stockholm: Almqvist and Wiksell, 1986), pp. 245-266.

3. Curtis Wilson, William Heytesbury: Medieval Logic and the Rise of Mathematical Physics (Madison: University of Wisconsin Press, 1956), especially pp. 32-56.

4. Among the most relevant studies are Norman Kretzmann, "Incipit/Desinit," in Motion and Time, Space and Matter, ed. P. K. Machamer and R. G. Turnbull (Columbus: Ohio State University Press, 1976), pp. 101-136; Kretzmann, "Socrates Is Whiter than Plato Begins To Be White," Nous 11 (1977): 3-15: John E. Murdoch and Edith Dudley Sylla, "The Science of Motion," in Science in the Middle Ages, ed. David C. Lindberg, (Chicago and London: University of Chicago Press, 1978), pp. 241-246; Murdoch, "Propositional Analysis," pp. 117-146; Murdoch, "The Analytic Character of Late Medieval Learning: Natural Philosophy without Nature," in Approaches to Nature in the Middle Ages, Medieval and Renaissance Texts and Studies 16 (Binghamton: SUNY Press, 1982), pp. 183-200; Lauge Olaf Nielsen, "Thomas Bradwardine's Treatise on 'Incipit' and 'Desinit'," CIMAGL 42 (1982): 6-43; Alain de Libera, "La problématique de l'instant du changement au XIII e siécle: Contribution à l'histoire des sophismata physicalia," in Studies in Medieval Natural Philosophy, ed. Stefano Caroti, Biblioteca di Nuncius: Studi e testi (Florence: Olschki, 1989), pp. 43-93.

5. See, for instance, Herman and Charlotte Shapiro, "De primo et ultimo instanti des Walter Burley," Archiv für Geschichte der Philosophie 47 (1965): 157-173; Nielsen, "Thomas Bradwardine's Treatise," pp. 47-83. Moreover, some mostly anonymous thirteenth-century sophismata on incipit and desinit have been edited very recently by Andrea Tabarroni, "'Incipit' and 'desinit' in a Thirteenth-Century Sophismatacollection," CIMAGL 59 (1989): 61-111; Alain de Libera, "Le sophisma anonyme 'Sor desinit esse non desinendo esse' du Cod. Parisinus 16135," CIMAGL 59 (1989): 113-120; Sten Ebbesen, "Three Thirteenth-Century Sophismata about Beginning and Ceasing," CIMAGL 59 (1989): 121-180. 
introduction to Wylton's text, I shall offer an analysis of the salient points of his treatment of the limit decision problem. Since Wylton's question originates from Aristotle's discussion about this topic in Physics 8.8, I shall first sketch the relevant Aristotelian background.

\section{THE ARISTOTELIAN BACKGROUND}

Aristotle deals with the limit decision problem in Physics 6.5 and 8.8.6 His own doctrine is extremely complicated and deserves an attentive examination. Such an effort, however, is beyond the scope of this essay. ${ }^{7}$ I shall rather restrict myself to indicating those elements of Aristotle's treatment that are essential for understanding the nature of the limit decision problem as discussed by Wylton. ${ }^{8}$

Schematically, this problem arises when one tries to describe a change which occurs within a continuous time. According to the Aristotelian definition of continuity, ${ }^{9}$ given any period of time, whatever instant one chooses within it, this instant divides (conceptually) the given period into two parts, and it represents the common limit at which they join. Thus, the dividing instant belongs to both temporal parts into which it divides a period of time and it must be regarded both as the last instant of the first part and as the first instant of the second part.

Aristotle and his medieval followers generally perceived no difficulties with this account of the continuity of time and, in particular,

6. Aristotle Physics 6.5 (236a7-b18), 8.8 (263b9-264a6).

7. For a detailed analysis and discussion of Aristotle's treatment of the limit decision problem, see especially Richard Sorabji, "Aristotle on the Instant of Change," Proceedings of the Aristotelian Society suppl. vol. 50 (1976): 69-89, repr. with revisions in Articles on Aristotle, ed. Jonathan Barnes, Malcolm Schofield, and Sorabji (London: Duckworth, 1979), 3:159-177; Sorabji, Time, Creation and the Continuum (London: Duckworth, 1983), pp. 403-418.

8. On the Aristotelian background of the medieval discussions, see also Wilson, William Heytesbury, pp. 29-32; Kretzmann, "Incipit/Desinit," pp. 101-103; Knuuttila, "Remarks on the Background," pp. 246-251; Nielsen, "Thomas Bradwardine's Treatise," pp. 6-8; and Kretzmann, "Continuity, Contrariety, Contradiction, and Change," in Infinity and Continuity in Ancient and Medieval Thought, ed. Kretzmann (Ithaca and London: Cornell University Press, 1982), pp. 270-274.

9. Aristotle Physics 5.3 (227a10-17). 
with the assumption that the same instant can serve both as a limit of one time-segment and as a limit of the next time-segment. ${ }^{10}$ Consequently, as far as the continuity of time alone is concerned, no limit decision problem arises, that is, it is not necessary to decide whether the dividing instant is to be ascribed to the first time-segment or to the second, since it can be safely ascribed to both.

A limit decision problem, however, does arise when a transition from one state to another occurs in the dividing instant, especially if the two states in question are contradictories, i.e., they allow no intermediate state. Taking one of the most common examples in medieval discussions, if the instant in which Socrates changes from being to not-being is focused on, then it seems impossible to maintain that this dividing instant belongs both to the period of time in which Socrates exists and to the period of time in which Socrates does not exist, i.e., that it is both the last instant of Socrates' being and the first instant of Socrates' not-being, since this would imply a violation of the law of non-contradiction, for in the same instant Socrates would exist and would not exist. ${ }^{11}$ Furthermore, it is impossible to maintain that this instant belongs neither to the period of time in which Socrates exists nor to that in which he does not, since this would imply a

10. A survey of the medieval treatment of Aristotle's theory of continuity is found in Annaliese Maier, Die Vorläufer Galileis im 14. Jahrhundert (Rome: Edizioni di Storia e Letteratura, 1949), pp. 155-179. See also Wolfgang Breidert, Das aristotelische Kontinuum in der Scholastik, BGPTMA NF 1 (Münster: Aschendorff, 1970). Wylton's discussion about continuity is mainly found in the first two questions on Physics 6: q. 1, "Utrum continuum permanens componatur ex indivisibilibus"; q. 2, "Utrum continuum successivum componatur ex indivisibilibus." The two are found in Cesena, Biblioteca Malatestiana, MS. Plut. VIII sin. 2, ff. 95va line 4-100va line 8 ab imo. In what follows, my references to Wylton's question "An contingit dare ultimum rei permanentis in esse" (Physics 8, q. 6) will be to the critical edition contained in the Appendix below, whereas my references to other sections of his Quaestiones libri Physicorum will be to this Cesena manuscript.

11. In solving the limit decision problem, however, a small group of medieval authors supported a doctrine that allows the simultaneous existence of contradictories. On this doctrine, see Simo Knuuttila and Anya Inkeri Lehtinen, "Change and Contradiction: A Fourteenth-Century Controversy," Synthese 40 (1979): 189-207; Knuuttila, "Remarks on the Background," pp. 258-261; Kretzmann, "Continuity," pp. 274-284; Paul V. Spade, "Quasi-Aristotelianism," in Infinity and Continuity in Ancient and Medieval Thought, ed. Kretzmann (Ithaca and London: Cornell University Press, 1982), pp. 297-307. 
violation of the law of the excluded middle, for in this instant Socrates would neither exist nor not exist. Thus, it is necessary to decide whether the instant of transition is to be assigned to the period in which Socrates exists or to that in which he does not. According to the first alternative, there is a last instant of Socrates' being, but there is no first instant of Socrates' not-being, or, equivalently, the period of time in which Socrates exists is limited intrinsically by the instant of transition, since this instant belongs to it, whereas the period of time in which Socrates does not exist is limited extrinsically by the instant of transition, since this instant does not belong to it. According to the second alternative, there is no last instant of Socrates' being, but there is a first instant of Socrates' not-being, i.e., Socrates' being is extrinsically limited, whereas Socrates' not-being is intrinsically limited.

The solution to the limit decision problem posed by a change occurring within a continuous time thus consists in the choice of one of the two alternatives just outlined. But for Aristotle himself and, more explicitly, for medieval authors there is no universal solution to this problem, in the sense that the ascription or the denial of a first instant or of a last instant to a state involved in a change depends on the permanent or successive nature of such a state. The most common distinction, therefore, invoked by medieval authors who deal with the limit decision problem is the distinction between permanent things, i.e., things whose parts exist simultaneously, as, for instance, an individual substance, and successive things, i.e., things whose parts exist only successively, as, for instance, a run made by Socrates.

Wylton himself uses this distinction. He devotes, however, no specific discussion to the limit decision problem concerning successive things. In regard to this issue he simply restates what is taken to be Aristotle's solution, according to which a successive thing is extrinsically limited both at its beginning and at its end.12 On the other hand, he is not completely satisfied with Aristotle's solution to the limit decision problem for permanent things. Aristotle deals specifically with the ceasing of a permanent thing, as for instance the passage from being white to being not-white, and he argues that

12. See Aristotle Physics 6.5 (236a7-18); Thomas Wylton In Physicam, ff. 104vb line $15 a b$ imo-105ra line 8 . 
there is no last instant of being white. The conclusion is that being white is extrinsically limited, since it is limited by the first instant of being not-white. Wylton agrees with Aristotle's conclusion about the denial of a last instant of being white, but he also maintains that this conclusion cannot be extended to all kinds of permanent things. ${ }^{13}$ Accordingly, the bulk of his question "An contingit dare ultimum rei permanentis in esse" is devoted to introducing subdivisions within the category of permanent things, to establishing to which kinds of permanent things a last instant of being is to be ascribed or denied, and to explaining the criteria on which such an ascription or denial is based.

The following analysis of Wylton's question is articulated in two parts. These parts correspond to the main distinction introduced by him into the category of permanent things, namely, the distinction between what he calls positive permanent forms (as, for instance, hot, fire) and privative permanent forms (as, for instance, not-hot, notrun). The nature of this distinction between positive and privative permanent forms is not completely evident and it seems difficult to find a clear-cut reason which led Wylton to introduce it. I shall go into more detail concerning this problem in the second part of my analysis. For the time being, I shall concentrate on Wylton's treatment of the limit decision problem in the case of positive permanent forms, which represents the major and most interesting section of his question.

\section{POSITIVE PERMANENT FORMS}

Wylton subdivides positive permanent forms into forms admitting a latitude of degrees in which they possess the form (latitudo in gradibus), i.e., a range within which their form can vary according to different degrees, and forms possessing invariable degrees. Under the first kind of forms he classifies, for instance, white, hot, fire, water; under the second kind of forms he classifies a particular degree of heat, the moving body's being in a particular place, and a quantity like two-cubits long. ${ }^{14}$

13. Thomas Wylton In Physicam 8.6, sections [2.1]-[2.5] and [3.8.2]-[3.8.3].

14. Thomas Wylton In Physicam 8.6, section [2.1] at "Intelligendo enim. ..." 
The classification of substantial forms, like that of fire or of water, under the class of forms having a latitude of degrees is in sharp contrast with the Aristotelian doctrine according to which substantial forms are indivisible. ${ }^{15}$ Wylton himself follows Aristotle's teaching in other sections of his commentary on the Physics, and he argues in these places that a substantial form is not subject to intension and remission of degrees. ${ }^{16}$ This contrast, however, only reflects Wylton's inaccurate use of the technical language of the intension and remission of forms in his description of the difference between two kinds of positive permanent forms. Yet this is irrelevant to the subsequent discussion about the problem of the last instant of being. For, in Wylton's view, what is relevant to this problem is not the difference in the ontological structure of these two kinds of forms, but a more physical difference, concerning the way in which both types of forms pass into not-being. A form having a latitude of degrees is corrupted through a temporal process during which it takes on successively different degrees until it is transformed into another form, whereas the passing into not-being of an indivisible form, as, for instance, a particular degree of heat, cannot be a temporal process during which it varies, since it admits no variation. On the other hand, although a substantial form does not in itself admit a latitude of degrees, nevertheless its corruption is a successive process, as Wylton argues at length in his commentary on Physics 5.17 During this process, the qualities which are essentially joined to this form (as, for instance, heat in the case of the substantial form of fire) undergo an intension or remission in degrees. Consequently, if the distinction between forms having a latitude of degrees and invariable forms is interpreted as a distinction between forms which pass into not-being during a period of time and forms which pass into not-being instantaneously, Wylton's classification of substantial forms under the class of forms that pass into not-being during a period of time is in agreement with his position on the nature of substantial change, i.e., generation and corruption.

15. Aristotle Metaphysics 8.3 (1043b32-1044a14).

16. See especially Thomas Wylton In Physicam 5.3, "Utrum ad substantiam sit

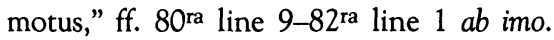

17. Thomas Wylton In Physicam 5.2, "Utrum generatio secundum quod est per se mutatio distincta a motu sit subita vel successiva," ff. $78^{\text {rb }}$ line $15-80^{\text {ra }}$ line 8 . 
The difference between the passing into not-being of forms having a latitude of degrees and that of invariable forms is regarded by Wylton as the main ground on which the solution of the limit decision problem for positive permanent forms must be based. From this difference he infers that for forms passing into not-being in time no last instant of being is to be ascribed, but such an instant is to be ascribed to forms passing into not-being instantaneously.

Wylton's argumentation in favor of this asymmetry in the solution of the limit decision problem for positive permanent forms is rather compressed, ${ }^{18}$ so that it is difficult to detect all the assumptions he uses and to spell out their interrelations. It is easier, however, and even more interesting, to attempt a reconstruction of the general strategy he adopts in dealing with this problem. In a preliminary way, this strategy can be outlined as follows: Wylton's argumentation stresses some specifically physical features of the passing into not-being of permanent forms; this leads him to stress also the relationship between the last instant of being of these forms and the last instant of the physical processes through which they change from being to not-being. As a result of this physical approach, the solution of the limit decision problem for permanent forms turns out to be almost completely determined by the solution of the same problem for successive things, and, in particular, for motion, a solution that, according to Wylton, has already been established by Aristotle in Physics 6.5.

In order to clarify the strategy just outlined, I shall exemplify it with the case of being hot (calidum) and the case of having a singular degree of heat, e.g., calidissimum. The passage from being hot to being not-hot, as, for instance, to being temperate, is described in physical terms as follows: the hot body, remaining hot, undergoes a temporal process (mutatio continua) consisting of the remission of heat, at the end of which it is no longer hot, but temperate. This description, however, does not hold for the alternation from having a singular degree of heat to not having it, since the indivisibility of such a degree is incompatible with the successive character of a change. In this case, one has to say that the body having a singular degree of heat is at rest with respect to this degree for some time, and when a differently qualified body starts acting on it, this degree is destroyed and so no longer exists.

18. Thomas Wylton In Physicam 8.6, sections [2.2]-[2.4]. 
According to this difference between the physical descriptions of passing into not-being of being hot and of particular degrees of heat, Wylton maintains that the instant of transition from being to notbeing must be differently described in the two cases: the instant of transition from being hot to being not-hot is the terminus mutationis, i.e., the final temporal limit of the change which takes place in the hot body, whereas the instant of transition from being calidissimum to being not-calidissimum is the terminus quietis, i.e., the final temporal limit of the body's state of rest with respect to being calidissimum.

On the other hand, the terminus mutationis does not belong to mutatio itself, since mutatio, being a successive entity, is extrinsically limited at its end. Rather it belongs to the state in which change has been completed. The terminus quietis, however, belongs to the state of rest, in the sense that in this terminus the body is still at rest with respect to being calidissimum. Wylton's main ground for this last conclusion depends, as it seems, once more on the solution of the limit decision problem for successive entities. ${ }^{19}$ In the case of a body changing from being calidissimum that he is considering here, the state of rest is followed by a state of change, namely, that in which the action exerted on it by a differently qualified natural substance has its effect. Thus the instant of transition between these two states can be regarded not only as the terminus quietis, but also as the principium motus. On the other hand, however, the principium motus does not belong to motion itself, because motion is extrinsically limited at its beginning. Therefore, Wylton concludes, it must belong to the state of rest with respect to being calidissimum.

Thus, the main result of Wylton's argumentation can be reformulated as follows: there is no last instant of a body's change from being hot to being not-hot, but there is a last instant of a body's resting with respect to a particular degree of heat.

It is clear that so far this result concerns the temporal limits of the change of the hot body and of the rest of the body having a particular degree of heat, but it does not yet concern the temporal limits themselves of being hot and of being characterized by a particular degree of heat. In order to fill in this gap, some assumptions about the relationship between the temporal extension of the existence of

19. Thomas Wylton In Physicam 8.6, section [2.4] at "Causa quare contingit dare...." 
motion and of rest and that of the existence of the forms involved in them are necessary.

Wylton himself resorts, more or less explicitly, to these kinds of assumptions. In the case of a body's change from being hot, he assumes that the existence of being hot is coextensive with that of this change. ${ }^{20}$ Accordingly, since there is no last instant of this change, there is no last instant of being hot, i.e., there is no last instant in the terminus mutationis when being hot no longer exists. In the case of a body's change from being calidissimum, he argues that the existence of being calidissimum is coextensive with the body's state of rest with respect to being calidissimum. Accordingly, since there is a last instant of rest with respect to being calidissimum, there is also a last instant of being calidissimum, i.e., there is a last instant in the terminus quietis when being calidissimum still exists. ${ }^{21}$

The asymmetry in the assignment of temporal limits to forms having a latitude of degrees and to invariable forms represents the major innovation which Wylton introduces into the traditional Aristotelian treatment of the limit decision problem for permanent entities, as it is found in Physics 8.8. Due to his innovation he will have to defend this asymmetry against some objections. 22

One of them in particular deserves a close examination, because it both points out the physical character of Wylton's approach to the

20. Thomas Wylton In Physicam 8.6, section [2.3] at "Tota autem causa ..."; see also section [3.1.1]. This assumption is used by Aristotle himself in the argument of Physics 8.8 (263b9-264a6). In other passages, however, he offers an analysis of change that contrasts with this assumption. In Physics 6.4 (234b10-20), for instance, he argues that during the change from one state to another both these states inhere partially in the changing body and not only the initial state. On this inconsistency in Aristotle's theory of change, see Sorabji, "Aristotle," pp. 78-85. There is no such inconsistency in Wylton's theory of change. He constantly supports the doctrine that, as long as a change lasts, only the initial state of this change inheres in the moving body and the final state does not yet exist. For Wylton's doctrine of change, see especially Thomas Wylton In Physicam 3.7, "Utrum motus sit aliquo modo in genere termini ad quem est motus," ff. 35 3 rb line 12 ab imo-39ra line 13.

21. Thomas Wylton In Physicam 8.6, section [2.4] at "Causa quare contingit dare. ..." For an analysis of the asymmetry between motion and rest, which Wylton exploits in his argumentation, see especially Sorabji, "Aristotle," pp. 71-77.

22. Thomas Wylton In Physicam 8.6, sections [1.7.1]-[1.8]. 
limit decision problem and it indicates some difficulties in his position. In this objection, ${ }^{23}$ it is assumed that a form having a latitude of degrees can vary between a minimum degree (gradus maxime remissus) and a maximum degree. On this basis the following inference is formulated: if there is a last instant of the existence of the minimum degree of heat, then there is also a last instant of the existence of being hot, since these two instants coincide. The validity of this inference is illustrated with the case of a body which rests under the minimum degree of heat for some time and then it is brought into contact with a cold body, which starts acting on it. If one allows a last instant of the body's resting with respect to the minimum degree of heat, then one is seemingly forced to allow also a last instant of the body's being hot, since the last instant of the body's resting with respect to such a degree is also the last instant of the body's being hot.

In order to avoid the inference from a last instant of a minimum degree of heat to a last instant of being hot, Wylton is expected to resort to some assumptions about the ontological structure of a form having a latitude of degrees. He might, for instance, deny a maximum and a mininum degree of heat. He does not, however, resort to this kind of assumption, but to a more physical kind. For the crucial point in his reply is not the denial of a minimum and a maximum degree of heat, but the denial of a natural body's rest with respect to these two extreme degrees. 24 Accordingly, he seems to maintain that these degrees are always acquired by the natural body during a process of intension or remission of heat.

Although Wylton does not clearly state his solution to the objection, it is apparently the following: if, for instance, the minimum degree of heat is acquired during a process of remission of heat, which ends at the reception of another quality, like temperate, then it is possible both to assign a last instant of being to such a degree and deny a last instant of being hot. For, during this change, the natural body takes on each degree of heat and, in particular, the minimum degree just for an instant (because otherwise it would be resting with respect to such a degree), which is consequently both the first and

23. Thomas Wylton In Physicam 8.6, section [1.7.4].

24. Thomas Wylton In Physicam 8.6, section [3.7.2]. 
the last instant of the existence of this degree. On the other hand, there is no last instant of being hot, since this instant is the terminus mutationis, in which, in Wylton's view, being hot no longer exists. ${ }^{25}$

Wylton's treatment of the objection based on the extreme degrees of a quality against the asymmetry in the solution of the limit decision problem for permanent forms is in agreement with the strategy he adopts in dealing with this problem, which has been outlined above. For, in order to show how it is possible to reconcile the assignment of a last instant of the extreme degrees of a quality and the denial of a last instant of this quality itself, Wylton assumes that a careful examination of the physical circumstances under which these qualitative determinations exist in natural substances is necessary.

Wylton's solution of this objection, however, is not fully satisfactory. To begin with, the crucial point of his solution is the denial of a natural body's rest with respect to the extreme degrees of a quality. Yet this is in contrast with his main argument in favor of the ascription of a last instant of being to an indivisible degree, in which the state of rest with respect to this degree is regarded as the essential requisite for such an ascription. Wylton perceives this inconsistency and he attempts a solution, which is, however, rather obscure. ${ }^{26}$

Secondly, even the denial of a body's rest with respect to the minimum and maximum degrees of heat, and the consequent claim that these degrees are always possessed by a natural substance during a process of intension or remission of heat, do not seem sufficient to avoid the objection against the asymmetry in the solution of the limit decision problem for permanent forms. For, regardless of the fact that the last instant of being of the minimum degree of heat occurs in a process of remission of heat or in a state of rest, the conclusion that this instant is also the last instant of being hot seems inevitable, since it follows from the definition of a minimum degree itself. Thus, in order to avoid the inference from the existence of a

25. This is probably the meaning of Wylton's argument in section [3.7.2] at "Nam, cum omnia talia...."

26. This solution consists of the following distinction: a natural substance, like fire, can be resting with respect to an extreme degree, like calidissimum, only when it is in its natural place, where no contrary natural substance exerts an action on it. Yet such a rest is impossible when fire is acted on by a contrary natural substance. Thomas Wylton In Physicam 8.6, sections [3.7.3]-[3.7.4]. 
last instant of the minimum degree of heat to the existence of a last instant of heat, it seems necessary to reject the existence of extreme degrees. A more adequate analysis of this problem, however, requires a careful investigation into Wylton's theory of the latitude of forms and of intension and remission processes, which will be the argument of another essay. 27

\section{PRIVATIVE PERMANENT FORMS}

In the second part of his discussion of the limit decision problem for permanent entities, ${ }^{28}$ Wylton deals with permanent forms that are "privations" of other forms, either successive, like non cursus, or permanent, like non album. These privations are distinguished from positive permanent forms.

Although he does not declare the nature of the distinction between positive permanent forms and privative permanent forms, this is very probably to be interpreted as a conceptual distinction, not as a real one. This means that there is only one kind of real permanent forms, according to Wylton, namely positive permanent forms. Yet each of them can be described as the privation of another form, as, for instance, temperate can be also described as not-hot. And although Wylton assumes that the ascription or the denial of temporal limits to permanent forms depends on their ontological and physical characteristics, and not on the conceptual ways in which they are described, nevertheless his discussion about the limit decision problem for privative permanent forms is not a mere repetition of his treatment of the case of positive permanent forms. This is due to the fact that he does not focus on the real nature underlying a privative form, but on the privative character itself and on the "positive" entity to which such a privation refers. Accordingly, Wylton draws some distinctions within the category of privative permanent forms which correspond to the main distinctions within the category of positive

27. For an analysis of similar problems which arise in Walter Burley's theory of qualitative change, see Edith Dudley Sylla, "Infinite Indivisibles and Continuity in Fourteenth-Century Theories of Alteration," in Infinity and Continuity, pp. 231-247.

28. Thomas Wylton In Physicam 8.6, section [2.5]. 
entities. ${ }^{29}$ Thus he distinguishes between two main kinds of privative forms. The first consists of forms that are privations of successive entities, as, for instance, not-run. The second consists of forms that are privations of permanent entities, like not-white. The latter kind is subdivided into two types: the first consisting of forms that are privations of forms having a latitude of degrees; the second consisting of forms that are privations of invariable forms. Consequently, because of Wylton's major concern with the privative character of privative permanent forms, it is not completely arbitrary to abandon in the following exposition the odd notion of privative permanent form and to speak, in a more traditionally Aristotelian way, of the "not-being" (non esse) of different kinds of entities, as Wylton himself does in his subsequent discussion. 30

Accordingly, the distinction between the two main parts into which Wylton's treatment of the limit decision problem is articulated can be more clearly reformulated as follows. In the first (concerning positive permanent forms) he deals with the ascription of temporal limits to the being of permanent things, whereas in the second (concerning privative permanent forms) he deals with the ascription of temporal limits to the not-being of both permanent and successive things.

On the other hand, once temporal limits have been assigned to the being of a certain thing, then, according to the common medieval view and to Wylton as well, the ascription of temporal limits to its not-being is reduced to a mere application of a general rule, which might be labelled the compatibility rule.

To put it in a synthetic way, the rule states that if intrinsic temporal limits are assigned to a thing's being, then extrinsic temporal limits must be assigned to its not-being, and, vice versa, if extrinsic temporal limits are assigned to its being, then intrinsic temporal limits must be assigned to its not-being.

29. Thomas Wylton In Physicam 8.6, section [2.5] at "De secundo membro... permanentium vel successivarum" and "Si loquamur de negatione ... alicuius perfectionis indivisibilis."

30. Thomas Wylton In Physicam 8.6, section [2.5] at "Si primo modo...." It should be noted, however, that the identification of a privative permanent entity with the not-being of another entity does not explain Wylton's insistence on the permanent character of such a privative entity. 
A complete formulation of this rule is found in Walter Burley's treatise De primo et ultimo instanti. ${ }^{31} \mathrm{He}$ articulates the compatibility rule in four rules, which derive from expressing temporal limits in terms of a first instant and a last instant and from taking into account both the case of a thing's being preceding its not-being and the case of a thing's being following its not-being. Thus, according to Burley's compatibility rules, for any entity there are only four admissible relations between the temporal limits of its being and of its not-being:

(1) If there is a first instant of its being, then there is no last instant of its not-being.

(2) If there is no first instant of its being, then there is a last instant of its not-being.

(3) If there is a last instant of its being, then there is no first instant of its not-being.

(4) If there is no last instant of its being, then there is a first instant of its not-being.

With the help of Burley's clear formulation, it is easy to find out that these four rules have a common ground. They are constituted by the necessity of ascribing the dividing instant between being and notbeing, namely, the instant of transition, to just one of these two states. Consequently, they can be regarded as an alternative formulation of the limit decision problem as I have outlined it in a previous section of this essay.

Although Wylton himself does not devote a separate exposition to the compatibility rules, he does rely on them in order to establish which kind of temporal limits must be ascribed to the not-being of an entity, once the temporal limits of its being have been ascribed. Thus, his solution of the limit decision problem for the not-being of an entity consists of three main conclusions which correspond to the three main kinds of entities he considers, namely, successive entities, variable permanent entities, invariable permanent entities:

(1) For successive entities, there is both a first instant and a last instant of not-being, since there is neither a last instant of being nor a first instant of being.

31. See Shapiro and Shapiro, "De primo et ultimo instanti," p. 166, lines 8-20. 
(2) For divisible permanent entities, there is a first instant of notbeing, since there is no last instant of being. There is, however, no last instant of not-being, since there is a first instant of being.

(3) For indivisible permanent entities, there is neither a first instant of not-being nor a last instant of not-being, since there is both a first instant and a last instant of being. ${ }^{32}$

In conclusion, the compatibility rules provide Wylton with an immediate solution to the limit decision problem for "privative permanent forms," since in virtue of them such a solution is completely determined by the results of his discussion about positive permanent forms and successive entities.

It should be remarked, however, that these rules, despite their logical character, impose some restrictions on the kinds of entities which can follow one another in time. The necessity for these restrictions becomes clear if, instead of speaking abstractly of the not-being of an entity, one asks more concretely which state or entity exists immediately before and immediately after its being. For instance, if a successive entity is considered, then according to the compatibility rule what exists immediately after it cannot be another successive entity, because both of them are extrinsically limited. Although Wylton was not completely unaware of this problem area, he does not, however, face it in his treatment of the limit decision problem. ${ }^{33}$

\section{CONCLUSION}

I shall conclude my introduction to Wylton's question "An contingit dare ultimum rei permanentis in esse" by identifying

32. Thomas Wylton In Physicam 8.6, section [2.5] at "Si successivarum, semper ... non mensuretur instanti, sed tempore" and "Si primo modo..." to the end of the section.

33. See especially Thomas Wylton In Physicam 6.2, "Utrum continuum successivum componatur ex indivisibilibus," ff. 97vb line 12 ab imo-100va line $8 a b$ imo; and 8.5 , "An motus reflexus sit unus simpliciter," ff. 129 ra line 16-131 $1^{\text {rb }}$ line 13 . For an analysis of the problem which arises in the transition from a successive state to another successive state, see especially Kretzmann, "Incipit/Desinit," pp. 114-116. 
its doctrinal and historical position within the medieval discussions of the limit decision problem.

As to the doctrinal context, I shall rely on the results of some comprehensive works on this problem, such as those by Wilson, Kretzmann, Murdoch, and Knuuttila. ${ }^{34}$ Schematically, these scholars distinguish two main strands in the medieval treatment of the limit decision problem: the physical strand and the logical strand. Roughly speaking, in the physical strand the objects of the analysis are physical entities, namely, first and last instants, and the tools of the analysis are physical theories, such as the continuity of time, the structure of change and of the formal determinations involved in change. In the logical strand the objects of the analysis are propositions containing the terms "incipit" and "desinit" and they are analyzed with logical tools or, to use J. E. Murdoch's expression, metalinguistically. ${ }^{35}$ Although propositional analysis is not totally absent in Wylton's discussion, ${ }^{36}$ the physical approach is, however, clearly dominant, since, as has been pointed out in the previous sections, the distinctions he draws into the category of permanent entities, the arguments he uses for establishing the main points of his solution and, finally, the most relevant objections he faces have all a physical meaning. Accordingly, Wylton's question must be regarded as an example of the physical approach to the limit decision problem.

Historically, a final identification of Wylton's position requires an investigation into the second half of thirteenth-century English tradition of commentaries on the Physics, which still has to be made. ${ }^{37}$

34. See especially Wilson, "William Heytesbury," pp. 31-56; Kretzmann, "Incipit/Desinit," pp. 103-121; Murdoch, "Propositional Analysis," pp. 118-138; Knuuttila, "Remarks," pp. 251-258.

35. See, for instance, Murdoch, "Propositional Analysis," p. 122.

36. See Thomas Wylton In Physicam 8.6, section [2.5] at "Et ideo, cum idem sit ... non mensuretur instanti, sed tempore" and section [3.3].

37. Silvia Donati and I are working on a set of (mostly anonymous) English commentaries on the Physics dating back to 1250-1270, which we plan to edit over the next few years. For the first results of our research, see Silvia Donati, "Per lo studio dei commenti alla Fisica del XIII secolo, I: Commenti di probabile origine inglese degli anni 1250-1270 ca. (parte I)," Documenti e studi sulla tradizione filosofica medievale 2 (1991): 361-442; Trifogli, "Le questioni sul libro III della Fisica in alcuni commenti inglesi intorno alla metà del XIII secolo (parte I)," Documenti e studi sulla tradizione filosofica medievale 2 (1991): 443-502. 
For the time being, it is possible, however, to assert that Wylton's treatment of the limit decision problem is not isolated in the medieval tradition, because it is closely associated with what is regarded as the most popular work on this topic, namely, Walter Burley's treatise De primo et ultimo instanti. ${ }^{38} \mathrm{~A}$ careful textual comparison has shown that there are several passages which occur, almost in an identical form, both in Wylton's question and in Burley's treatise. ${ }^{39}$ Since Wylton's commentary on the Physics is likely to have been written before Burley's De instanti, 40 then, provided that there is no third common source, Wylton's question is to be regarded as the main source of Burley's treatise. ${ }^{41}$

Scuola Normale Superiore

Pisa

38. A detailed exposition of this work is given by Paola Feltrin and Massimo Parodi, "Il problema del primo e ultimo istante in Walter Burley," Medioevo 9 (1983): 137-178. See also Wilson, "William Heytesbury," pp. 32-33; Murdoch and Sylla, "Science of Motion," pp. 242-243; Nielsen, "Thomas Bradwardine's Treatise," pp. 1517; Calvin G. Normore, "Walter Burley on Continuity," in Infinity and Continuity, pp. 265-267.

39. Edith Sylla has first called my attention to the similarities between these texts. She noticed that the passage of Burley's De instanti that I quote in the Appendix at section [2.1] is found also in Wylton's question. See Edith Dudley Sylla, "Medieval Concepts of the Latitude of Forms: The Oxford Calculators," AHDLMA 40 (1973): 223-283, at p. 234. In the Appendix, I give a more complete list of the passages which are common to Wylton's question and Burley's De instanti.

40. Although neither of the two works have been dated with certainty, Burley's treatise is a disputatio de quolibet held in Toulouse before 1320-1324 and after 13081310 , whereas Wylton's commentary on the Physics was probably written before 13041305. On the dating of Burley's De instanti, see especially Agustín Uña Juarez, La filosofía del siglo XIV: Contexto cultural de Walter Burley (San Lorenzo de El Escorial: Biblioteca "La Ciudad de Dios," 1978), pp. 25, 70-71, 77-78; Sylla, "Walter Burley's Tractatus primus: Evidence Concerning the Relations of Disputations and Written Works," Franciscan Studies 44 (1984): 257-274, at pp. 257-259, 261. Walter Burley is also known to have incepted in Theology under Thomas Wylton. See, for instance, Uña Juarez, Filosofía del siglo XIV, pp. 22-25.

41. I wish to thank Professor Stephen F. Brown for his suggestions in writing this article and for his help in improving my English. I am also grateful to Dr. Concetta Luna for her careful review of the critical edition of Wylton's question contained in the appendix. 


\section{APPENDIX}

This appendix contains a critical edition of Thomas Wylton's question "An contingit dare ultimum rei permanentis in esse." This edition is based on the four manuscripts of Wylton's Quaestiones libri Physicorum which are known at present:

$\mathrm{C}=$ Cesena, Biblioteca Malatestiana, MS. Plut VIII sin. 2, ff. 131rb-133rb (XIVth century)

$\mathrm{E}=$ Erfurt, Stadtbibliothek, MS. Ampl. Fol. 178, ff. 69vb-70vb (XIVth century)

$M=$ Madrid, Biblioteca Nacional, MS. 2015, ff. 204r-207v (XVth century)

$\mathrm{V}$ = Città del Vaticano, Biblioteca Vaticana, MS. Vat. Lat. 4709, ff. 135rb-137rb (XIVth-XVth century)

Since I am also preparing a complete critical edition of Wylton's Quaestiones libri Physicorum, I postpone both the description of the manusripts and a full discussion of the textual tradition presented by them until the publication of that work. Hence the present edition aims at making available the content of Wylton's question rather than at representing a final contribution to the edition of Wylton's Quaestiones libri Physicorum. In this context, however, I shall summarize the main results of the collation of the four manuscripts relative to 8.6.

The four seem to derive from a common source, which is distinct from the archetype. This is suggested both by the occurrence of cases where all four offer the same wrong reading (in [1.2], intrinsecus instead of finitum; in [1.7.3], calidum instead of calidissimum; in [2.3], corruptum instead of corrupta; in [2.4], the omission of in quo and est; in [3.1.2], ipsum instead of $i p s a)$ and by the occurrence of cases where none of the four offers a correct reading (see, for instance, [2.4] and [3.1.1]).

$\mathrm{C}$ and $\mathrm{E}$ seem to form a couple, because the cases where they agree against the other manusripts are comparatively frequent: they have thirty-seven common variant readings, whereas $M-V$ have eleven, $E$ $\mathrm{V}$ have eleven, E-M have six, C-V have three, C-M have none. The relationship between $C$ and $E$ is still unclear. It can be noted that the text offered by $\mathrm{E}$ is more faulty than that offered by $\mathrm{C}$, because it presents several homoioteleuton omissions (eleven, whereas $\mathrm{C}$ has only four).

No other definite grouping can at present be shown to exist among the manusripts. It is very likely that $\mathrm{M}$ does not belong to the grouping 
C-E, because it has only five variant readings common to C-E. On the other hand, it cannot be established whether $\mathrm{V}$ belongs to the grouping C-E or it does not, and, in the latter case, whether it forms a grouping with $M$ or not, since $V$ agrees with $C-E$ against $M$ in sixteen cases, but also with $M$ against $C-E$ in eleven cases. Moreover, both $M$ and $\mathrm{V}$ have a great number of particular variant readings (i.e., variant readings that appear in only one manuscript): $M$ has $189, \mathrm{~V}$ has 174 , whereas $C$ has 74 and $E$ has 75 .

Because of the lack of quality of the texts offered by $M$ and $V$, the present edition is mainly an attempt at a reconstruction of the text offered by C-E. This means that in those cases where C-E offer a variant reading which is equivalent to that offered by the others, the variant reading of C-E has been adopted (see, for instance, [Quaestio], [1.5], [1.10], [2.4], [3.1.2]).

\section{[THOMAS WYLTON QUAESTIONES LIBRI PHYSICORUM 8.6]}

Quaeritur an contingit dare ultimum rei permanentis in esse in quo contingit dicere "nunc hoc est et postea non erit."

\section{[1. ARGUMENTA PRO ET CONTRA]}

Quod sic videtur:

[1.1] quia omne quod est in tempore quia in instanti, ita quod non est in tempore nisi quia in instanti primo, si habeat esse finitum, habet aliquod instans in quo est sibi correspondens postquam non erit; forma permanens est huiusmodi; ergo etc. Maior probatur, quia ex quo habet esse finitum habet aliquam mensuram in qua finitur suum esse et per consequens in qua ultimatim est; cum ergo sua mensura propria sit instans, erit ponere aliquod instans in quo ultimatim est. Minor manifesta est, quia per hoc distinguitur esse permanens ab esse successivo, quia permanens mensuratur instanti et successivum tempore.

[1.2] Item, cuiuslibet finiti sunt duo termini intrinseci, aliter finitum non esset in se finitum; sed esse durativum Sortis est quoddam finitum in se; ergo habet duos terminos intrinsecos terminantes ipsum; ergo 
sicut est dare primum sui esse, ita et ultimum. Nec valet dicere quod ultimum sui esse sit non esse, quoniam esse durativum, ex quo est finitum in se, terminum intrinsecum habebit sibi, non esse autem non est intrinsecum ipsi esse.

[1.3] Item, si non est dare ultimum, haec consequentia est bona "tu es; ergo tu eris," cum tamen haec consequentia non valeat. Consequentia patet, quia si tu es modo et tui esse non est ultimum, ergo habebis esse post hoc; et sic arguam de illo esse in infinitum. Ex quo sequeretur quod semper eris. Quod tamen consequentia non valeat "hoc est; ergo hoc erit" probatur, quia antecedens est determinate verum, consequens autem, cum sit de futuro in materia contingenti, est indeterminate verum.

[1.4] Praeterea, non currere mensuratur instanti et habet esse durativum, sicut forma permanens in subiecto apto nato, et tamen contingit dare ultimum non cursus. Nam in instanti in quo aliquis incipit currere non est cursus et tunc ultimo est non cursus; ergo contingit dare ultimum rei permanentis.

[1.5] Item, VI huius ${ }^{1}$ Aristoteles arguit sic: si motus esset in instanti, ergo in quolibet instanti et per consequens in ultimo. Sic arguo hic: cum forma permanens nata est esse in instanti, ergo erit in quolibet instanti et sic per consequens in ultimo, vel ratio Philosophi ibi non valebit.

[1.6] Item, per Philosophum, ${ }^{2}$ contingit dare primum instans in quo aliquid est; contingit ergo vere dicere, quando ex aere fit ignis, quod nunc primo est ignis. Sed sequitur: nunc primo est ignis; ergo immediate ante hoc fuit non ignis, ut aer; sed esse aeris est mensuratum instanti; ergo in aliquo instanti immediate ante hoc fuit aer et tunc ultimo, cum statim absque medio fit ignis.

[1.7.1] Item, pono quod aliquid quiescat sub gradu caliditatis perfectissimo per totum tempus $a c$ et quod in termino indivisibili $c$ sit approximatum summe frigidum in illa proportione in qua hoc sit natum agere et illud pati. Certum est, retento opposito, in $c$ est calidissimum et numquam post $c$ erit calidissimum. Quod sit calidissimum in $c$ patet, quia in instanti non est actio. Quod non sit post calidissimum probatio, quia, si sic, sequeretur quod agens esset approximatum passo per tempus in quo natum est hoc agere et hoc pati 
et etiam in proportione illa in qua natum est hoc agere et hoc pati, et tamen nec hoc ageret nec hoc pateretur, quod est impossibile. Quod hoc sequatur patet, quia, si frigidum ageret in illo tempore, cum sua actio agat per contrarietatem remittendo caliditatem in passo, oportet dare quod caliditas in passo remitteretur, vel si non, sed maneret sub eodem gradu nunc et prius, sequeretur quod non mutaretur nec per consequens ab alio pateretur.

[1.7.2] Huic rationi dicitur concedendo quod est dare ultimum instans in quo aliquid dicitur calidissimum, tamen non contingit dare ultimum instans in quo aliquid est calidum. Unde in formis absolutis, quarum esse manere potest sub diversis gradibus perfectionis, non contingit dare ultimum, tamen in formis talibus secundum quod comprehendunt determinatum gradum perfectionis, cum talis gradus in indivisibili consistit, ita quod quaecumque variatio modica variat substantiam gradus et secundum nomen et secundum rationem, in talibus bene contingit dare ultimum.

[1.7.3] Contra: primo probo quod non est dare ultimum in quo est forma sub illo gradu. Nam per Philosophum in littera, ${ }^{3}$ omne quod prius est non ens et postea est ens oportet aliquando quod fiat ens. Aliam propositionem ponit ${ }^{4}$ similiter quod, cum aliquid fit, non est. Ex his arguo: accipio illud instans quod tu dicis esse ultimum in quo hoc est calidissimum. Si ergo fiat post non calidissimum, hoc erit per aliquod fieri medium; sed certum est quod non fit non calidissimum in instanti in quo est calidissimum. Nam fieri, cum sit mutari, non est in instanti. Nec etiam fit non calid[issim]um quando iam est non calid[issim]um; ergo in aliquo tempore medio fit non calidissimum; sed quod fit non est; ergo in illo toto tempore medio non est non calidissimum, et si hoc, per locum a contradictione sequitur: ergo calidissimum est; ex quo sequitur quod ultimum datum non sit ultimum. Et sicut arguitur de isto ultimo dato, sic argui potest de quolibet ultimo in infinitum, et per consequens impossibile est dare ultimum in quo est calidissimum.

[1.7.4] Item, probo quod eo ipso quod est dare ultimum alicuius talis gradus quod est dare ultimum esse formae absolutae, puta ultimum in quo aliquid est calidum. Nam per eandem rationem qua tu ponis unum gradum secundum quem aliquid est calidissimum, qui gradus 
ita in indivisibili consistit quod, si aliquid perfectionis addatur, non potest salvari natura caloris, ita contingit dare aliquem gradum ita remissum caloris quod, si in aliquo ulterius remitteretur, variaretur species calidi et fieret sub alia specie, puta tepidi. Arguo tunc sic: pono quod aliquid quiescat per tempus $a c$ sub illo gradu caloris maxime remisso et quod in instanti $c$ occurrat ei corpus frigidissimum. Quaero an in illo instanti $c$ ultimo sit sub illo gradu vel non. Si non, sequeretur, ut prius argutum est, ${ }^{5}$ quod, agente approximato passo et in debita proportione et in debita mensura, nec hoc agat nec illud patiatur. Si detur quod sic, ergo in illo instanti est verum dicere quod est ultimo calidum, quoniam simul desinit ille gradus caloris et species caliditatis per positum, ex quo ille gradus est maxime remissus sub quo natura calidi potest salvari. Et idem argumentum potest fieri de igne et de aqua.

[1.8] Item, causa quare contingit dare primum in quo res facta est et non ultimum, ut primum ignis et non ultimum aeris, videtur esse quia corruptio formae prioris est inductio formae posterioris, et forma posterior, cum inducta sit in instanti, tunc est, forma autem prior, cum corrupta sit in eodem instanti, tunc non est. Et ideo, cum sit dare primum instans in quo est forma sequens, non est dare ultimum esse formae prioris. Ergo cum eadem sit causa in proposito-nam manente caliditate in sua specie, non corrumpitur gradus nisi per inductionem gradus contrarii vel incompossibilis-gradus ille, quicumque sit, inductus est in instanti et in eodem instanti corrumpitur gradus primus; ergo cum in illo instanti gradus posterior est, gradus autem prior non est, sed corruptus est, videtur quod non contingit magis dare ultimum in quo aliquis gradus caloris est quam sit dare ultimum in quo forma caloris est.

[1.9] Aliae fiunt hic rationes multae, sed omnes positae sunt et solutae prius, vel in IV, in quaestione de tempore minimo, ${ }^{6}$ vel in VI, ubi quaerebatur an continuum successivum componatur ex indivisibilibus. ${ }^{7}$

5. See [1.7.1].

6. In this question, however, the only reference to the limit decision problem is the following: "Similiter rationes de ultimo rei permanentis in esse faciunt hic, de quibus patebit in suo loco" (Thomas Wylton In Physicam 4.24, f. 73ra line 1 ab imo to $73^{\text {rb }}$ line 1 .

7. Thomas Wylton In Physicam 6.2, f. 99rb lines 22-26. 
[1.10] Ad oppositum est Philosophus in littera. ${ }^{8}$

\section{[2. DETERMINATIO QUAESTIONIS]}

[2.1] Ad quaestionem dicendum distinguendo quod per rem permanentem contingit duo intelligere: vel formam positivam aliquam cuius esse existit totum simul, vel non solum formam positivam, sed indifferenter positivam vel privativam, dummodo eius esse tale quale habet totum simul est, et isto modo non album potest dici forma permanens. Et utrumque istorum membrorum est ulterius distinguendum. Intelligendo enim per rem permanentem aliquam formam positivam, adhuc hoc contingit dupliciter: vel enim illa forma habet latitudinem in gradibus, ita quod, corrupto uno gradu, potest eadem forma manere sub alio, vel illa forma importat perfectionem aliquam secundum gradum punctualem. ${ }^{9}$ Exemplum primi: album, calidum, ignis, aer, aqua. Omnia enim ista habent latitudinem in gradibus et sub tota latitudine salvari possunt. Exemplum secundi: in motu locali est hoc ubi signatum in quo est mobile in principio motus vel in medio; similiter, bicubitum, tricubitum in motu augmenti; similiter, calidissimum, frigidissimum et omnes huiusmodi gradus in motu alterationis.

[2.2] Loquendo de formis primo modo dictis, impossibile est dare ultimum rei permanentis in esse in quo forma corrumpenda habeat esse, et de talibus formis habet intelligi processus hic Philosophi; 10 loquendo de formis secundo modo dictis, non.

[2.3] Ratio primi est ista: in talibus formis, cum non corrumpantur nisi per motum vel per mutationem, tota mutatio continua cadit super formam priorem cuius mutationis continuae terminus est corruptum esse illius formae. Et quia in eodem instanti forma aliqua corrupta est et forma contraria inducta est, sequitur, ut dicit Philosophus, ${ }^{11}$ si aliquis daret ultimum in quo esset forma prior, cum idem sit instans mensurans ultimum prioris formae et principium posterioris, aliter non esset tempus continuum, necesse esset concedere quod vel aliquid,

8. Aristotle Physics 8.8 (263b9-26).

9. On Wylton's theory of the latitude of forms, see especially Thomas Wylton, In

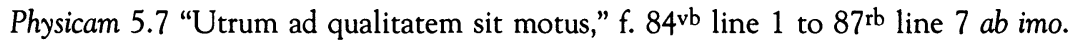

10. Aristotle Physics 8.8 (263b9-264a1).

11. Aristotle Physics 8.8 (263b9-26). 
quando factum est, non esset, et cum corruptum est, esset, aut quod simul aliquid esset et non esset, quorum utrumque est impossibile. Tota autem causa huius est quia in transmutatione talis formae mutatio continua cadit super formam priorem, quae mutatio terminatur ad mutatum esse illius formae, quod est eius corruptum esse, et ad inductum esse formae contrariae, et per consequens forma prior in illo instanti non est, cum corrupta sit. Et ideo necesse est dicere in talibus quod in illo instanti ultimo res denominetur a posteriori passione, ut dicit Philosophus. ${ }^{12}$

[2.4] Ratio secundi est ista, quia tales perfectiones in indivisibili consistunt, ita quod, sicut in numeris, quocumque abstracto vel amoto, variatur tota substantia illius perfectionis, ideo nulla mutatio continua potest cadere super talem gradum vel talem perfectionem formae, manente gradu eodem quo prius, et ideo tota continuitas cadit in talibus supra non esse talium, et hoc sive non esse praecedat esse sive econtra. Unde si ex non calidissimo fiat calidissimum vel ex non bicubito bicubitum vel ex non hoc ubi in hoc ubi, non contingit dare ultimum alicuius non esse, sed primum esse. Si autem fiat mutatio econtra ex calidissimo in non calidissimum vel ex bicubito in non bicubitum et sic de aliis, contingit dare ultimum quietis sub calidissimo et similiter sub bicubito, sed non contingit dare primum non esse alicuius talis. Causa quare contingit dare ultimum quietis est quia res, dum quiescit, eodem modo se habet nunc et prius in omni signo, et per consequens in termino quietis, cum idem sit terminus quietis et principium motus, adhuc - certum est-non mutatur; et si hoc, sequitur quod, si prius fuit calidissimum, adhuc est calidissimum. Causa autem quare non contingit dare primum [in quo] non est calidissimum [est] quia ab illo instanti quod est finis quietis sub gradu priori patitur per motum contrarii agentis ipsum calidissimum, ratione cuius continue aliter et aliter se habet, et ideo sicut non contingit dare primam partem in motu nec etiam primum mutatum esse, sic non contingit dare primum non esse illius gradus vel primum inductum esse gradus incompossibilis. Et ideo quia in talibus formis non est dare primum non esse, ideo non est mirum etsi sit dandum ultimum esse.

[2.5] De secundo membro, si per rem permanentem non solum intelligat formas positivas, sed negationes talium formarum, distinguo: vel illae negationes sunt negationes formarum permanentium vel 
successivarum. Si successivarum, semper contingit dare ultimum. Et causa est quia non est dare primum alicuius successivi, puta in motu nec primum mutatum esse nec primam partem. Et ideo, cum idem sit terminus quietis et principium motus, in illo termino quietis verum erit dicere "nunc mobile ultimo non movetur." Nec valet instare per hoc quod pro tanto tunc ultimo non movetur, quia in instantibus sequentibus adhuc etiam non movetur, cum in instanti non sit motus, quia, sicut dictum est in prima quaestione IV huius, ${ }^{13}$ in quolibet instanti continuante partes motus et temporis verum est dicere quod mobile movetur, ita quod veritas propositionis seu compositionis praedicati ad subiectum instanti mensuratur, quamvis ipsum praedicatum non mensuretur instanti, sed tempore. Si loquamur de negatione formae permanentis, adhuc distinguendum est. Vel enim est negatio formae habentis latitudinem in gradibus vel est negatio alicuius perfectionis indivisibilis. Si primo modo, numquam contingit dare ultimum non esse alicuius formae, tamen bene contingit dare primum non esse. Loquendo de non esse secundo modo, numquam contingit dare nec ultimum non esse nec primum non esse. Et causa est quia talis gradus contingit dare primum sui esse et etiam ultimum sui esse, et per consequens, eo quod est dare primum esse talis gradus, non est dare ultimum non esse. Similiter, eo quod est dare ultimum sui esse, non est dare primum sui non esse.

\section{[3. RESPONSIO AD ARGUMENTA]}

[3.1] His intellectis ad rationes: Ad primam ${ }^{14}$ dicendum primo ad maiorem, postea ad minorem.

[3.1.1] Ad maiorem, quod ipsa falsa est. Et ad probationem, quando accipitur quod ex quo eius esse est finitum, si non sit ultimum instans in quo est, oportet dare aliquam aliam mensuram in qua ultimatim foret, dico quod non sequitur, quia ultimum sui esse, cum sit ultimum sui mutationis per quam transmutatur in formam contrariam, est eius corruptum esse, et ideo in eius ultimo sibi nullum esse debetur nec per consequens mensura mensurans suum esse.

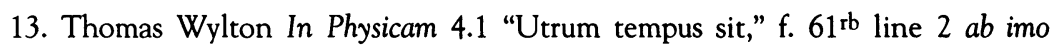
to $61^{\text {va }}$ line 24 .

14. See [1.1]. 
[3.1.2] Similiter, minor patitur calumniam. Cum dicitur quod forma permanens mensuratur instanti tanquam propria mensura, quaero an intelligit per instans instans secundum esse vel instans secundum substantiam. ${ }^{15} \mathrm{Si}$ primo modo, propositio falsa est. Instans enim secundum esse est propria mensura mutati esse in motu. Unde etsi res permanens mensuretur instanti secundum esse, hoc non est in quantum permanens, sed in quantum est sub aliquo mutato esse correspondente mutato esse in potentia in primo motu. Accipiendo ergo sic formam permanentem ut sub motu, bene concedo quod contingit dare ultimum instans in quo est sub ultimo mutato esse eius, quod est eius corruptum esse, sed in illo instanti ultimo forma permanens non est, cum corrupta sit. Si intelligat per instans instans secundum substantiam, sic potest concedi minor, quoniam ad formam permanentem proprie loquendo duae requiruntur condiciones: una quod nata sit habere esse continuum per quod distinguitur ab his quae raptim transeunt, cuiusmodi sunt mutata esse in motu et indivisibilia in tempore; alia condicio est quod ipsa secundum substantiam totum esse habeat simul in uno instanti quod habet in toto esse suo continuo, ita quod esse substantiale maneat, varietur tamen secundum esse accidentale. Tale autem est esse instantis secundum substantiam. Est enim instans et manens per totum tempus, habens tamen totum suum esse simul, invariabile etiam secundum substantiam, variabile secundum esse accidentale. Si ergo intelligat in minori quod forma permanens mensuratur instanti secundum substantiam, concedo. Et quando ulterius arguitur "ergo est dare aliquod instans in quo est postquam non est," dico quod non est dare instans secundum substantiam nisi tantum unum in toto tempore, et loquendo de illo instanti concedo quod in illo instanti ultimo est et non erit postea, quia nihil erit post illud instans, cum sit aeternum.

[3.2] Ad aliud ${ }^{16}$ dicendum concedendo, cum esse durativum huius formae sit finitum, quod eius erit dare ultimum. Unde concedo quod est dare ultimum sui esse et hoc est suum corruptum esse, sed non est dare suum ultimum esse, hoc est in quo verum sit dicere ipsum ultimo esse. Unde breviter non habet alium terminum ultimum nisi

15. On Wylton's treatment of the distinction between these two kinds of instants, see his In Physicam 4.22 "Utrum instans maneat unum et idem in toto tempore," $\mathrm{f}$. $68^{\text {ra }}$ line 11 to f. 69ra line $4 a b$ imo.

16. See [1.2]. 
suum non esse. Et quando arguitur quod non esse non potest esse terminus intrinsecus ipsius esse, dicendum quod non esse potest intelligi dupliciter: vel absolute, et sic esse et non esse, cum contradicant, neutrum est terminus alterius. Similiter, ut sic non includunt aliquam continuitatem nec per consequens aliquem terminum habent. Alio modo potest esse intelligi ut stat sub mutatione continua per quam tendit ad non esse, et ut sic est eius terminus non esse nec alium terminum intrinsecum habet in actu. Nec prohibet hoc quod non esse non est eiusdem rationis cum esse, quia hoc non requiritur in mutationibus, sicut patet in generatione quae comprehendit alterationem praecedentem. Continuitas enim ibi attenditur penes qualitates formae corrumpendae, terminus tamen illius mutationis est substantia. $\mathrm{Nec}$ est dare ibi aliquem terminum ipsius alterationis circa formam accidentalem, et sic nec hic.

[3.3] Ad aliud17 dicendum quod bene sequitur "hoc est; ergo hoc erit." Intelligendo consequens ut hoc verbum "erit" copulat vage non pro aliquo supposito futuri signato, concedo quod, si hoc est, ergo hoc erit per infinita instantia quorum quodlibet sequitur aliud secundum divisionem temporis in partes eiusdem proportionis, non eiusdem quantitatis. Nec sequitur "erit per infinita instantia; ergo semper erit," sed est fallacia consequentis, quoniam antecedens est verum de minima parte temporis. In minima enim parte temporis quae signari potest sunt infinita instantia quorum quodlibet est post aliud, sed "semper" distribuit pro omni parte temporis potentiali et actuali. Ulterius, quando accipitur quod consequens est indeterminate verum, dicendum quod est determinate verum, supposito antecedente. Unde licet "hoc erit" de forma sua non sit determinate verum-nam demonstrato supposito futuro, ut Antichristus, non est determinate verum-supposito tamen quod hoc sit in hoc nunc, consequens est determinate verum. Unde per accidens est quod talis propositio de futuro sit determinate vera.

[3.4] Ad aliud ${ }^{18}$ patet in positione. ${ }^{19}$

[3.5] Ad aliud ${ }^{20}$ patet in VI huius in loco suo. ${ }^{21}$

17. See [1.3].

18. See [1.4].

19. See [2.5].

20. See [1.5].

21. See Thomas Wylton In Physicam 6.7, f. 102 va lines 10-6 ab imo; f. 102vb lines 16-3 ab imo. 
[3.6] Ad aliud 22 dicendum quod non sequitur "nunc primo est ignis; ergo immediate ante fuit non ignis," quia nulla mensura fuit immediate ante. Nam, ut dictum est, ${ }^{23}$ signato aliquo indivisibili, nihil est dare immediatum sibi nec divisibile nec indivisibile, et si hoc, nihil est dare immediatum ante nec immediatum post.

[3.7] Ad aliud ${ }^{24}$ dicendum ut dicebatur. ${ }^{25}$

[3.7.1] Ad primum in contrarium ${ }^{26}$ dicendum quod Philosophus non vult dicere quod inter non esse, ut est quoddam continuum terminatum per esse, et esse cadat fieri medium, sed intelligit quod inter quodcumque instans signatum in quo est sub non esse et instans signatum in quo est sub esse cadit fieri medium. Sic concedo hic quod inter hoc instans in quo ultimo est calidissimum et quodcumque instans signatum in quo est non calidissimum cadit fieri medium. Et concedo quod in illo medio mobile non est non calidissimum illo gradu caliditatis inter quem et calidissimum mediat ipsum fieri, est tamen sub alio gradu non caliditatis in potentia, nec est dare primum gradum in quo est non calid[issim]um.

[3.7.2] Ad aliud 27 dicendum quod calidum, frigidum et huiusmodi qualitates habent diversos gradus secundum hoc quod consequuntur diversa corpora naturalia. Alius est calor et alios terminos habens prout consequitur formam aeris et formam ignis. Ergo si ratio habeat difficultatem per hoc quod ponit remiss[issim]um gradum vel perfectissimum, hoc erit circa aliquod corpus naturale, puta circa ignem vel aerem vel aliquid tale. Et tunc dico quod impossibile est quod quiescat sub remississimo gradu vel perfectissimo. Nam, cum omnia talia corpora sint activa et passiva ad invicem, sicut non contingit dare ultimum esse talis formae in quo talis forma est, ita non contingit dare ultimum gradum caliditatis in quo caliditas ultimo est, sed sicut terminatur esse prioris formae ad inductum esse formae sequentis et non ad aliquod esse ultimum intrinsecum, ita nec remissio in qualitatibus vel etiam intensio. Supposito quod aliquid posset intendere calorem igneum ultra proportionem suae formae, non contingit dare aliquod ultimum in quo est sub caliditate ignea.

22. See [1.6].

23. Thomas Wylton In Physicam 6.2, f. 99va line $2 a b$ imo to 99vb line 4.

24. See [1.7.1].

25. See [1.7.2].

26. See [1.7.3].

27. See [1.7.4]. 
[3.7.3] Dicetur: istud videtur contra praedicta. Concessum enim est prius $^{28}$ quod ignis possit quiescere sub gradu calidissimo.

[3.7.4] Dicendum quod iste gradus, scilicet calidissimus, vel potest comparari ad ignem relictum propriae naturae non admixtum contrario nec passum a contrario agente, sicut est de igne in medio sphaerae suae, et sic ignis bene potest quiescere sub illo gradu et quantum est ex se illum gradum sibi determinat. Similiter etiam potest ignis quiescere sub multis gradibus remissioribus, tamen nec sub gradu remississimo nec intensissimo quem potest habere a contrario agente potest quiescere; immo, cum aqua sit naturaliter frigida et aer calidus, nihil prohibet aquam passam esse calidiorem aere.

[3.8.1] Ad ultimam rationem ${ }^{29}$ dicendum quod non est eadem causa. Nam in formis habentibus latitudinem secundum gradus mutatio continua se tenet ex parte formae corrumpendae et terminatur ad formam inducendam tanquam ad terminum in actu. Unde in motu, quamvis non sit dare primum mutatum esse in potentia, contingit tamen dare primum mutatum esse in actu; sed in corruptione gradus indivisibilis mutatio continua se tenet ex parte negationis. Nam ille gradus manens idem non mutatur, sed quaecumque variatio ex parte gradus, ut dictum est, tollit illum gradum, et ideo corruptio illius gradus non est per aliquid incompossibile actu inductum quod sit primus terminus illius mutationis in quo est sub non calidissimo, sicut ex alia parte inductum esse ignis est primum in quo est non aer, sed ante quemcumque gradum est gradus in infinitum, propter quod non est simile.

[3.8.2] Adhuc posset aliquis dicere ex quo, ut dictum est, quod non est dare ultimum esse formae permanentis, mirabile videtur quod Philosophus ${ }^{30}$ universaliter et absque distinctione determinat quod non est dare ultimum, sed primum.

[3.8.3] Dicendum quod Philosophus nec illam quaestionem movet nec eam solvit, sed solum respondet uni obiectioni quae solebat fieri in generabilibus et corruptibilibus, scilicet in igne et aere et talibus formis, ubi corruptio unius terminatur ad generationem esse alterius, sicut mutatio continua ad suum terminum, et in talibus, ut dictum

28. See [2.4].

29. See [1.8].

30. Aristotle Physics 8.8 (263b9-12). 
est, est universaliter verum quod non est dare ultimum non esse vel esse prioris passionis, cum sit dare primum posterioris.

\section{VARIANT READINGS}

The variants given here are keyed to phrases within sections of the text edited above. Only trivial variants have been left out (e.g., ergo / igitur). The orthography has been normalized according to classical standards.

[Quaestio]

Quaeritur om. EV

an I utrum $\mathrm{V}$

contingit dare I contingat dare $\mathrm{V}$

contingit dicere I contingat dicere $\mathrm{V}$

nunc hoc inv. MV

hoc est I hoc esse $\mathrm{V}$

[1.1]

non erit I non esse $\mathrm{V}$

in tempore quia $\mid$ est quod $M$

in instanti ita $\mid$ instanti ita $C$, in instanti est ita $M$

in instanti primo $/$ instanti primo $C$, in instanti prius $E$

esse finitum I esse infinitum CE

in quo est sibi $\mathrm{I}$ in quo enim sibi $\mathrm{V}$

ex quo habet esse finitum habet aliquam mensuram $\mid$ ex quo finitum habere men'suram $\mathrm{E}$ qua ultimatim est $\mid$ qua ultimatum est $C$, qua ultimate $M$, qua ultimatum $\mathrm{E}$

sua mensura inv. $\mathrm{V}$

quo ultimatim I quo ultimatum $\mathrm{CE}$, quo ultimate $\mathrm{M}$

quia per hoc I per hoc quod $\mathrm{V}$

ab esse successivo I ad esse successivum $C E$, a successivo $V$

quia permanens $I$ quod permanens $C$

mensuratur instanti et $\mid$ mensuratur in instanti et $\mathrm{E}$, mensuratur in instanti $\mathrm{V}$

tempore I tempori $\mathrm{V}$ 
[1.2]

Item, cuiuslibet | Item cuilibet $\mathrm{C}$

finiti sunt duo termini intrinseci $\mid$ finiti sunt termini intrinsecus $\mathrm{E}$ aliter finitum I scripsi, aliter intrinsecus CEMV

sed esse durativum Sortis I sed esset durativum Sortes V

est quoddam finitum I esse quoddam finitum $M$

ergo habet duos terminos I habet igitur duos terminos $\mathrm{E}$

terminos intrinsecos terminantes $\mid$ terminos sibi determinantes

intrinsecos (sed corr. in intrinsecos determinantes) $M$

ita et ultimum I et ultimum $\mathrm{M}$, ita ultimum $\mathrm{E}$

quoniam esse durativum $\mathrm{I}$ quoniam est durativum $\mathrm{V}$, quoniam esse

duratum $\mathrm{C}$

ex quo est finitum $\mid$ ex quo est infinitum $E$

habebit sibi, non esse autem I habebit sui non esse aliter $M$

non est intrinsecum ipsi $\mid$ non esset intrinsecum ipsi $M$

[1.3]

tu eris I eris $\mathrm{E}$

haec consequentia I consequentia $\mathrm{V}$

et tui I tui $\mathrm{V}$

ergo habebis esse I ergo habebit esse $M$

in infinitum $\mid$ infinitum $C E$

semper eris I semper erit $M$

Quod tamen consequentia | Quod autem haec consequentia $M$,

Quod consequentia tamen $\mathrm{V}$

quia antecedens I quia accidens $\mathrm{C}$

determinate verum I determinatum verum $\mathrm{V}$

futuro in materia $\mid$ futuro $\mathrm{M}$

[1.4]

currere mensuratur $\mid$ currere in (interl.) $M$, currere mensuratur in $\mathrm{V}$

Nam in instanti I Nam instanti C

in quo aliquis $\mathrm{I}$ in quo aliquid $\mathrm{CEV}$

et tunc ultimo est non cursus om. hom. E

ergo contingit dare I ergo contingit $\mathrm{M}$

[1.5]

Aristoteles I Philosophus M 
esset in instanti I esset instanti C ergo in quolibet $\mathrm{I}$ igitur erit in quolibet $\mathrm{V}$

arguo hic I arguo $\mathrm{V}$

cum forma permanens $\mid$ forma permanens $M$

esse in instanti I esse instanti $\mathrm{C}$

ergo erit in $\mathrm{I}$ ergo est in $\mathrm{V}$

et sic per I et per $\mathrm{V}$

[1.6]

contingit dare primum I contingit primum CE

in quo aliquid est $I$ in quo $M$, in quo aliquid CE

contingit ergo vere $\mathrm{I}$ continuum ergo vere $V$, contingit verum $M$, ergo contingit verum $\mathrm{E}$

quando ex aere I cum quod ex aere $\mathrm{V}$

quod nunc primo ... hoc fuit non ignis iter. hom. V

ignis, ut aer ... ante hoc fuit om. hom. CE

ignis, ut aer I ignis vel aer $\mathrm{M}$

est mensuratum instanti I est mensuratum in instanti $\mathrm{V}$

aliquo instanti immediate $\mid$ aliquo instanti in quo aliquis quiescit

mediate scr. et corr. M

et tunc ultimo $\mid$ et tunc ulterius $\mathrm{M}$

[1.7.1]

pono quod aliquid I pono quod aliquis EM

quiescat sub gradu caliditatis I quiescat sub gradu caloris $M$

tempus $a c$ et $\mathrm{I}$ tempus et $\mathrm{V}$

et quod in termino $\mathbf{l}$ et in termino $\mathrm{E}$, et quod in toto $\mathrm{M}$

in illa proportione $\mid$ in ista proportione $M$

et illud pati I et pati C

retento opposito | forte pro: isto casu posito (cfr. Texts from Burley

ad loc.), retento posito $M$

in $c$ est calidissimum $\mathrm{I}$ in $c$ calidissimum $\mathrm{V}$

post $c$ erit calidissimum $\mid$ post $c$ est calidissimum $M$

Quod sit calidissimum I postquam sit calidissimum M in $c$ patet I c ibi patet $\mathrm{V}$

quia in instanti $\mid$ quia instanti $C$

post calidissimum probatio $\mid$ calidissimum probo $M$, post calidum probatio $\mathrm{V}$ 
et etiam in proportione illa $I$ et in proportione ista $M$, et etiam in illa proportione $\mathrm{E}$ agere et hoc om. hom. CEM nec hoc pateretur I nec pateretur hoc E Quod hoc sequatur patet I Quod autem hoc sequatur M ageret in illo tempore $\mathrm{I}$ ageret in isto tempore $\mathrm{M}$ cum sua actio agat $I$ cum agens agat $M$, cum sua agat $C$

dicitur concedendo quod I dicitur concedo quod M quo aliquid dicitur calidissimum $\mid$ quo aliquid dividitur calidissimum $\mathrm{C}$, quo aliquid calidissimum dicitur $\mathrm{V}$ in quo aliquid est $\mathbf{I}$ in quo, in quo aliquid est est $\mathrm{M}$ Unde in formis absolutis $\mid$ in formis absolutis $E$, Unde in formis absolute $\mathrm{V}$

quarum esse manere $\mathrm{I}$ quarum est manere $\mathrm{E}$ determinatum gradum perfectionis $\mid$ gradum perfectionis determinatum $M$

[1.7.3]

gradus in indivisibili $\mathrm{I}$ gradus indivisibilis $\mathrm{V}$

probo quod non est $I$ probo quod non contingit $M$

forma sub illo gradu | forma sub gradu isto $M$ aliquando quod fiat ens I quod aliquando fiat ens $M$

Aliam propositionem ponit $\mathrm{I}$ similem propositionem ponit $\mathrm{M}$, ad propositum ponit $\mathrm{V}$

cum aliquid fit $\mathrm{I}$ cum aliquid sit $\mathrm{C}$ accipio illud instans $\mid$ accipiendo illud instans $\mathrm{E}$ post non calidissimum I primo non calidissimum $\mathrm{V}$ hoc erit per aliquod I hoc est per aliquod V quod non fit non I non (2) interl. M in instanti in quo est calidissimum $\mid$ instanti in quo est calidum $\mathrm{C}$, in instanti in quo est calidum $\mathrm{E}$

non est in instanti $\mid$ non fit in instanti $V$, non est instanti $C E$ nec etiam fit $I$ nec etiam sit $C$ quando iam est non calid[issim]um $\mid$ om. hom. M, quanto iam est calidum $\mathrm{CE}$, quanto iam est non calidum $\mathrm{V}$ medio fit non calidissimum $\mid$ medio fit non calidum $M$, medio fit nunc calidissimum $\mathrm{C}$ 
est ergo in illo toto $\mid$ ergo est in illo toto $\mathrm{CE}$, ergo est in toto isto $\mathrm{M}$

non est non calidissimum $\mid$ non est calidissimum $E$, non est non calidum V

et si hoc $\mid$ et sic hoc $M$

ergo calidissimum est $\mid$ ergo est calidum $M$, ergo calidissimum $C E$ sicut arguitur de isto $\mathrm{I}$ sic arguit de isto $\mathrm{V}$

sic argui potest $\mathrm{I}$ sicut argui potest $\mathrm{V}$

de quolibet ultimo in $\mid$ de quibusdam ultimo $C$, de quocumque dato in $M$

dare ultimum in quo est $\mid$ dare ultimum (interl.) in quo est $\mathrm{M}$ in quo est calidissimum ... gradus quod est dare ultimum om. hom. E

in quo est calidissimum $\mid$ in quo est calidum $M$

[1.7.4]

Item, probo I corr. in Item probem (?) V

esse formae absolutae $\mid$ formae absolutae E, esse formale absolutae $\mathrm{V}$

non potest salvari natura $\mathrm{I}$ non potest salvare natura $\mathrm{V}$

caloris ita contingit dare aliquem gradum | ita contingit dare aliquem gradum caloris $M$

ita remissum caloris quod | ita remissum caloris qui $\mathrm{C}$

variaretur species calidi | varietur species calidi $\mathrm{EV}$, varietur species calida $\mathrm{C}$

tempus a $c$ sub illo $\mid$ tempus $a c$ sub isto $M$

quod in instanti $c \mid$ in instanti c $M$, quod instanti $c$ C

occurrat ei corpus frigidissimum | occurrat ei corpus frigidum $M$

an in illo instanti $c \mid$ an illo instanti $c \mathrm{~V}$, an in isto instanti c $\mathrm{M}$ sub illo gradu vel I sub gradu illo vel E

Si non, sequeretur I Si non sequetur CE

ut prius argutum est $\mid$ ut prius dictum est $M$

agente approximato passo $\mid$ agente approximata passo $\mathrm{C}$

nec hoc agat nec I natura hoc agat nec $\mathrm{C}$

quod est ultimo calidum $\mid$ quod ultimo calidum est $M$, quod est ultimum calidum $\mathrm{V}$ desinit ille iter. V

species caliditatis per positum I species caliditatis proportionatum

C 
ex quo ille gradus I ex quo ipse gradus $M$ potest salvari iter. $M$

[1.8]

in quo res facta est $\mid$ in quo res est facta $M$

ut primum ignis $\mathrm{I}$ et primum ignis $\mathrm{V}$ inducta sit in instanti I inducta sit instanti C sit in eodem instanti $\mid$ sit in instanti eodem $M$ Et ideo, cum I non add. interl. M

sit dare primum instans $\mid$ sit dare ultimum instans $M$, sit dare ultimum eam (?) CE

nam manente caliditate I non manente caliditate $\mathrm{V}$

gradus contrarii vel I impossibilis add. sed exp. C

vel incompossibilis—gradus ille I vel impossibilis gradus iste $M$ est in instanti I est eodem instanti $\mathrm{C}$

cum in illo instanti 1 cum illo instanti MV, cum in eodem instanti $\mathrm{E}$

gradus posterior est I gradus posterioris est C

gradus autem prior non est $\mathrm{I}$ gradus autem prioris non est $\mathrm{V}$

contingit magis dare ultimum $\mid$ contingit dare ultimum magis $M$ in quo aliquis gradus caloris $\mathrm{I}$ in quo aliquid gradus caloris $\mathrm{V}$ in quo forma caloris est $\mathrm{I}$ in forma caloris $\mathrm{M}$

[1.9]

Aliae fiunt | Aliae sunt $M$ in $I V$, in quaestione $\mathrm{I}$ in quarta quaestione $\mathrm{V}$ quaestione de tempore minimo $\mid$ quo determinatur de numero $M$ an continuum successivum $\mathrm{I}$ an continuum susceptivum $\mathrm{E}$ [1.10]

Philosophus in littera | Philosophus in textu M

[2.1]

dicendum distinguendo quod $\mathrm{I}$ dicendum quod $\mathrm{V}$, dicendum distinguendo $\mathrm{CE}$

formam positivam aliquam $\mid$ formam positam aliquam $\mathrm{C}$, formam positivam alicuius $M$

cuius esse existit I esse cuius existit $C$, esse cuius consistit $V$, cuius esse consistit $M$

formam positivam, sed indifferenter positivam $\mid$ formam positam sed indifferenter positam $\mathrm{C}$ 
dummodo eius esse tale $\mid$ dummodo esse eius tale $\mathrm{E}$ membrorum est ulterius distinguendum $\mid$ membrorum est ultimo distinguendum $\mathrm{M}$, membroum est ulterius distinctum $\mathrm{V}$ Intelligendo enim per rem I Intelligo enim per rem $\mathrm{V}$ permanentem aliquam formam positivam $I$ permanentem aliquam formam positam $\mathrm{C}$

adhuc hoc contingit dupliciter I adhuc contingit dupliciter E, adhuc hoc hoc contingit dupliciter $\mathrm{M}$, adhuc hoc contigit dare dupliciter $\mathrm{V}$

vel enim illa forma I vel enim ista forma $M$ potest eadem forma manere $I$ potest eadem forma remanere $E$ sub alio, vel illa I sub alia vel illa CEV, sub alio vel ista $M$ Exemplum primi: album, calidum I Exemplum primi: calidum $\mathrm{V}$ Omnia enim ista habent I Omnia ista habent V latitudine salvari possunt | latitudine salvari possunt. Intelligendum tamen quod est dare ultimum esse non quando aliquod mobile manens cedit ab aliquo vel signata, tamen supposito quod aliquid corrumpatur in aliquo signato non contingit dare magis ultimum esse ubi quam ultimum esse divisibile $\mathrm{V}$

similiter, bicubitum, tricubitum $\mid$ similiter bicubitum et tricubitum $\mathrm{V}$

similiter, calidissimum, frigidissimum $\mid$ similiter calidum et frigidum $\mathrm{V}$

Loquendo de formis I Loquendo de primis formis $\mathrm{V}$

primo modo dictis I primo dictis $\mathrm{E}$

in quo forma corrumpenda $I$ in quo forma corrupta $M$, in quo forma corrumpatur et $\mathrm{V}$

et de talibus formis I de talibus formis $\mathrm{V}$

habet intelligi processus $\mid$ habet intelligi huius processus $\mathrm{E}$ hic Philosophi I hic phisice V secundo modo dictis, non $I$ secundo modo dictis EV [2.3]

tota mutatio continua I tota autem mutatio continua CEV corruptum esse illius formae I corruptum esse istius formae $M$ Et quia in eodem instanti | Quia in eodem instanti E, Et quia in eodem in instanti $M$ 
forma aliqua corrupta $\mid$ forma alia corrupta C, forma autem corrupta $\mathrm{V}$

contraria inducta est I est om. CE, interl. M

in quo esset forma prior $I$ in quo est forma prior $E$

et principium posterioris I et ultimum posterioris $\mathrm{CEV}$

aliter non esset tempus I aliter non est tempus $\mathrm{V}$

concedere quod vel aliquid I concedere quod nihil aliquid $\mathrm{CM}$, concedere quod nihil aliud $\mathrm{V}$

quando factum est $\mathrm{I}$ quando factum $\mathrm{E}$, quando positum $\mathrm{V}$, est interl.

C

cum corruptum est I cum corruptum V

esse illius formae | esse istius formae $M$

quod est eius corruptum I quae est eius corruptum $\mathrm{V}$

cum corrupta sit I scripsi, cum corruptum sit CEMV

necesse est dicere in talibus $I$ necesse est dicere talibus $\mathrm{E}$

[2.4]

quia tales perfectiones $\mid$ quod tales perfectiones $M$

sicut in numeris I sicut numerus EV

quocumque abstracto vel amoto I quocumque substracto vel amoto

$\mathrm{M}$, quocumque abstracto vel remoto $\mathrm{V}$

nulla mutatio continua I nulla mutatio $\mathrm{V}$

potest cadere super talem gradum $\mid$ potest esse super talem gradum

$\mathrm{E}$, potest cadere supra talem gradum $\mathrm{V}$

manente gradu eodem I manente eodem gradu $M$

non esse talium $\mid$ non esse talium graduum MV

et hoc sive non I sive non $M$

sive econtra I vel econtra $\mathrm{V}$

si ex non calidissimo I si non ex calidissimo CE

ex non bicubito bicubitum I non ex bicubito bicubitum CE, ex

bicubito bicubitum $\mathrm{V}$

vel ex non hoc ubi I vel non hoc ubi $\mathrm{M}$

esse sed primum esse I scripsi, esse nisi primum esse CE, esse nisi

ipsum esse $\mathrm{M}$, esse non primum esse $\mathrm{V}$

econtra ex calidissimo in $\mid$ in interl. $\mathrm{V}$

sub calidissimo et similiter...contingit dare ultimum quietis I

om. hom. E 
dare primum non esse I sicus add. sed exp. C

Causa quare contingit dare I Causa autem quare contingit dare $M$ ultimum quietis est quia I ultimum quietis quia $\mathrm{V}$

dum quiescit, eodem modo $I$ dum quiescit eo modo $E$, quae dicitur quiescere eodem modo $\mathrm{M}$

cum idem sit terminus quietis $\mathrm{I}$ om. hom. V

et principium motus, adhuc $\mathrm{I}$ et primum motus adhuc $\mathrm{C}$ non est calidissimum $\mathrm{I}$ non esse talis $\mathrm{M}$, non calidissimum $\mathrm{V}$ sub gradu priori I sub gradu posteriori C, sub gradu particulari (?) E

sic non contingit dare I sic nec contingit dare $\mathrm{C}$ primum non esse illius gradus $\mathrm{I}$ non esse illius gradus $\mathrm{V}$, non esse istius $M$

esse gradus incompossibilis I esse gradus impossibilis E non est dare primum $\mid$ non est dare $\mathrm{V}$ dare primum non esse ideo $\mid$ dare primum non esse et ideo $M$ non est mirum etsi I vero est mirum etsi $\mathrm{E}$ sit dandum ultimum esse $\mid$ sit dandum ultimum non esse CEV [2.5]

De secundo membro, si I De secundo membro scilicet $M$ non solum intelligat $\mid$ non solum intelligas $M$ talium formarum, distinguo $\mathrm{I}$ est distinguendum $\mathrm{V}$ distinguo: vel illae negationes sunt negationes formarum $\mid \mathrm{om}$. hom. E

vel illae negationes sunt $\mid$ vel istae negationes sunt $M$, vel illae negationes talium sunt $\mathrm{V}$

et principium motus $\mathrm{I}$ et principium motus et $\mathrm{V}$

in illo termino quietis $\mid$ in isto termino quietis $M$ verum erit dicere "nunc I verum est dicere nunc $E V$, verum erit dicere non $M$

Nec valet I Si etiam vellet $V, N e c M$, in add. sed exp. C valet instare I valet instatur $M$ adhuc etiam non movetur I adhuc autem motus non movetur $\mathrm{E}$ non movetur, cum in $\mid$ in om. $C$, interl. $M$ dictum est in prima $\mid$ dictum est in primo $E$, dictum est in potentia $\mathrm{V}$ 
quaestione IV I IV quaestione CE quolibet instanti continuante I quolibet instanti $\mathrm{V}$ praedicatum non mensuretur I in add. V instanti sed tempore $\mid$ instanti sed in tempore $M$ Si loquamur I scilicet loquamur $\mathrm{C}$, Si loquatur $\mathrm{M}$ adhuc distinguendum est $\mid$ adhuc est distinguendum $M$, adhuc distinguendum $\mathrm{CE}$ negatio formae habentis I negatio conformae habentis C alicuius perfectionis indivisibilis $\mid$ alicuius indivisibilis perfectionis inv. $\mathrm{M}$

numquam contingit dare I numquam attingit dare $\mathrm{C}$ dare primum non esse $\mid$ dare non esse primum $M$ non esse. Loquendo . . gradus contingit dare primum iter. hom. C bene contingit dare primum non esse $\mid$ secundo modo numquam contingit dare nec ultimum non esse nec principium esse et causa est quia talis gradus contingit dare primum non esse add. E Et causa est quia | contingit dare primum non esse. Loquendo de non esse secundo numquam contingit dare nec ultimum non esse nec primum non esse, quia contingit dare primum non esse. Loquendo de non esse secundo modo numquam contingit dare nec ultimum non esse nec primum non esse et causa est quia add. iter.V

contingit dare primum sui ... primum esse talis gradus om. hom. E sui esse et etiam I esse sui et etiam $\mathrm{V}$, sui esse et per consequens M

ultimum sui esse I ultimum sui non esse $\mathrm{V}$

eo quod est dare I quod est dare C Similiter, eo quod est dare I Similiter dico quod est dare M [3.1]

His intellectis ad rationes $\mid$ His igitur intellectis respondetur ad rationes et primo $M$ Ad primam dicendum primo $\mid$ Ad primam dicendum $M$ postea ad minorem. Ad maiorem om. hom. M

[3.1.1]

quod ipsa falsa est I quod falsa est $M$, quod ipsa est falsa $V$ oportet dare aliquam aliam I oportet dare aliquam $\mathrm{V}$ 
aliquam aliam mensuram $\mid$ in qua sit in instanti add. $E$, in qua sit instanti add. $\mathrm{C}$, in qua sit quam in instanti add. MV

in qua ultimatim $\mid$ in qua ultimate $M$

ultimum sui mutationis $\mid$ ultimum mutationis $V$, ultimum suae mutationis $\mathrm{M}$, ultimum sui transmutationis $\mathrm{E}$

per quam transmutatur $\mid$ per quam transit $M$

ultimo sibi nullum esse | ultimo non esse sibi M, ultimo super (?)

nullum esse $\mathrm{E}$, ultimo sibi unum esse $\mathrm{C}$

forma permanens mensuratur $\mathrm{I}$ in add. EV

quaero an intelligit $\mid$ quaero an intelligat $M$

instans instans I instans CEV

propositio falsa est I propositio est falsa MV

Instans enim secundum esse I Instans enim secundum CE

est propria mensura mutati ... instanti secundum esse iter. hom. C est propria mensura mutati I est propria mensura mutatum $\mathrm{V}$ etsi res permanens mensuretur $\mathrm{I}$ etsi res permanens mutetur $\mathrm{V}$ Accipiendo ergo sic formam permanentem ut sub motu $\mid$ Accipiendo ergo sic forma permanentem ut sub motu C, Accipiendo ergo sic forma permanente ut sub motu $\mathrm{E}$, ut sic add. M quod est eius corruptum $\mid$ quod eius est corruptum C, quod est corruptum E

sed in illo instanti I sed in isto instanti ME

$\mathrm{Si}$ intelligat per I Si vero intelligat per $\mathrm{M}$

instans secundum substantiam $\mid$ instans secundum aliam $C$ potest concedi minor I potest concedi maior $\mathrm{V}$

ad formam permanentem proprie $\mid$ ad formam manentem proprie $\mathrm{M}$

una quod nata I una quae nata $\mathrm{CE}$

sit habere esse continuum $\mid$ sit habere continuum esse $\mathrm{E}$ raptim transeunt I sive moventur add. $M$

motu et indivisibilia $\mid$ motu indivisibilia EM

alia condicio est $\mid$ alia condicio CE

quod ipsa secundum I scripsi, quod ipsum secundum CEMV

in toto esse suo $\mathrm{I}$ in termino suo $\mathrm{E}$, in toto suo $\mathrm{CV}$

quod esse substantiale maneat $\mathrm{I}$ quod esse substantiae medietas $\mathrm{V}$ 
secundum esse accidentale | secundum esse actuale $M$

esse instantis secundum substantiam | esse instans secundum substantiam $\mathrm{V}$

Est enim instans I Est enim stans V

simul, invariabile $\mid$ et add. $\mathrm{M}$, simul et variabile $\mathrm{E}$ etiam secundum substantiam variabile om. hom. V

secundum esse accidentale I secundum esse accidentalia C Si ergo intelligat $\mathrm{S}$ Si ergo intelligant $\mathrm{V}$

in minori quod forma $\mid$ in minore quod forma $C$

forma permanens mensuratur $\mathrm{I}$ forma permanens mensurati $\mathrm{V}$

Et quando I Et quod C

ulterius arguitur | ulterius accipitur E

est postquam non est $\mid$ erit post quod non est $M$, erit postquam non est $\mathrm{E}$

unum in toto tempore $\mathrm{I}$ unum in tempore $\mathrm{V}$

loquendo de illo instanti | loquendo de isto instanti $M$

concedo quod in illo $\mathrm{I}$ concedo quo illo $\mathrm{V}$, concedo quod in isto $\mathrm{M}$

instanti ultimo est I instanti ultimo E

quia nihil erit I quod nihil erit $\mathrm{C}$ post illud instans $\mathrm{I}$ per illud instans $\mathrm{V}$

[3.2]

cum esse durativum $\mathrm{I}$ tamen esse durativum $\mathrm{V}$

huius formae sit finitum I huius formae sic finitum $\mathrm{V}$

quod eius erit dare I quod eius est dare MV

esse et hoc est suum I et hoc est suum V

sed non est dare I sed non est MV

dare suum ultimum esse $\mid$ dare sic ultimum esse $M$

breviter non habet alium | breviter non habet nullum $M$

dicendum quod non esse potest $\mid$ dicendum quod esse potest $M$

non esse potest intelligi dupliciter $\mid$ non esse potest sumi dupliciter $\mathrm{M}$

et sic esse et non esse $\mid$ et sic non esse et esse $M$

includunt aliquam continuitatem $\mid$ includunt aliam incontinuitatem $\mathrm{C}$, includunt aliquam incontinuitatem $\mathrm{E}$, includunt aliquam contrarietatem $\mathrm{M}$ 
aliquem terminum habent $\mid$ alium terminum habent $M$, aliquem terminum habet $C E$, alium terminum habet $V$

Alio modo potest ... tendit ad non esse transp. $3.3 \mathrm{M}$ potest esse intelligi I potest intelligi $\mathrm{E}$, potest intelligi esse $\mathrm{V}$ ut stat sub mutatione I ut stant sub mutatione $\mathrm{V}$ non esse non est I non esse est CEV quia hoc non requiritur $\mathrm{I}$ quia cum non requiritur $\mathrm{E}$ patet in generatione I patet in genere $\mathrm{V}$

Continuitas enim ibi | Continuans enim ibi V, Continuitas enim E

corrumpendae, terminus tamen 1 correspondentis terminus cum C, corruptae tamen cum termino $\mathrm{V}$

terminus tamen illius $\mid$ tamen terminus illius $\mathrm{E}$, terminus tamen istius $M$

illius mutationis est I illius mutationis in $\mathrm{CV}$

Nec est dare I non est dare CEV

ibi aliquem terminum I ibi alium terminum $\mathrm{V}$

alterationis circa formam accidentalem $\mid$ mutationis circa formam actualem $\mathrm{M}$, alterationis citra formam accidentalem $\mathrm{CE}$

et sic nec hic I sicut hic $\mathrm{CE}$, sic nec hic $\mathrm{V}$

Intelligendo consequens I intendendo consequens $\mathrm{V}$

copulat vage I copulatur vage $\mathrm{V}$

supposito futuri signato $\mathrm{I}$ supposito futuri signando $\mathrm{V}$ concedo quod si I concedendo quod si E si hoc est I si hoc erit CEV

ergo hoc erit I iter. C, ergo hoc erit secundum (vel sed) hoc erit add. E

erit per infinita $I$ in add. $M$

quodlibet sequitur aliud I aliud corr. mg. ex ad C, id est add. M non eiusdem quantitatis $\mid$ non tamen eiusdem quantitatis $M$ erit per infinita instantia I per infinita instantia erit $\mathrm{V}$ sed est fallacia consequentis I sed erit fallacia consequentis $\mathrm{V}$ quoniam antecedens est verum $\mid$ quoniam antecedens erit verum $\mathrm{V}$

quae signari potest I post de minima parte temporis $M$, quae assignari potest $\mathrm{V}$ 
quodlibet est post aliud I quodlibet aliud V, quodlibet est prius aliud C

sed "semper" distribuit I sed semper describit M

pro omni parte I Alio modo potest... tendit ad non esse transp. ex $3.2 \mathrm{M}$

accipitur quod consequens $\mathrm{I}$ accipitur quod consequentia $\mathrm{V}$

est indeterminate verum I est indeterminata verum $\mathrm{V}$

"hoc erit" de I hoc hoc erit CE, hoc de M

sit determinate verum I supposito tamen add. (tamen exp.) V

nam demonstrato supposito I nam corr. in non $C$, nam supposito determinato $\mathrm{M}$, nam demonstratio supposito $\mathrm{V}$ futuro, ut Antichristus... verum-supposito I om. hom. CE Antichristus | anticristo $M$

Unde per accidens I verumtamen per accidens $M$ [3.4] [3.5]

patet in positione $\mathrm{I}$ patet in ratione $\mathrm{M}$, patet in quaestione $\mathrm{EV}$

in VI huius in loco suo $\mid$ VI huius in suo loco $M$ et add. interl. in [3.6] quaestione septima

ergo immediate ante I ergo ante immediate $\mathrm{M}$ Nam, ut dictum est I non ut dictum est CE signato aliquo indivisibili $\mid$ signato aliud indivisibile $\mathrm{C}$, signato aliquid indivisibile $\mathrm{E}$, signato aliquod indivisibile $\mathrm{V}$ nihil est dare immediatum | nihil est immediatum dare $M$ sibi nec divisible I sibi $\mathrm{V}$ sibi nec divisibile... est dare immediatum om. hom. CE nihil est dare immediatum $\mid$ nihil est immediatum dare $M$ nec immediatum post $\mathrm{I}$ nec immediate post $\mathrm{C}$

[3.7.1]

quoddam continuum terminatum $\mid$ quod continuum terminatum

$\mathrm{C}$, continuum terminatum $\mathrm{E}$ et esse cadat I cadat MV

fieri medium I super medium C sed intelligit I si intelligat $\mathrm{V}$ inter quodcumque instans signatum | inter quaecumque signatum $\mathrm{M}$ 
non esse et ... in quo est sub om. hom. E

esse cadit fieri I esse cadat fieri $\mathrm{V}$

Sic concedo hic I et concedo hoc $\mathrm{V}$, sic concedo $\mathrm{M}$

inter hoc instans $\mid$ inter hoc $\mathrm{M}$

in quo ultimo est $I$ in quo est $M$, in quo ultimum est $C E$

in quo est non $\mathrm{I}$ in quo non est $\mathrm{V}$

in illo medio mobile | in isto medio mobile $M$

non est non calidissimum I non est calidissimum MV

est tamen sub alio $\mid$ esse tamen sub alio EM, erit tamen sub alio

$\mathrm{V}$

nec est dare primum $\mid$ nec est primum CE

[3.7.2]

dicendum quod calidum, frigidum $\mid$ dicendum quod caliditas, frigiditas V

alios terminos habens prout consequitur $\mid$ alios terminos habet potest consequi $\mathrm{V}$

formam aeris I forma aeris $\mathrm{V}$

Ergo si ratio habeat difficultatem $\mid$ ideo si ratio habet difficultatem

$\mathrm{V}$, diffinitam (?) add. E

hoc quod ponit I simul add. M

remiss[issim]um I suum CE

circa aliquod corpus I contra aliquod corpus $\mathrm{V}$

aliquod corpus naturale I et add. C

puta $\mathrm{I}$ et tu praem. CE

circa ignem vel aerem I contra ignem vel aerem $\mathrm{V}$

impossibile est quod quiescat $\mathrm{I}$ impossibile est quod quiescant $\mathrm{V}$

remississimo | remisso EMV

Nam, cum omnia I vel cum omnia C

omnia talia corpora I omnia corpora talia $\mathrm{M}$

talis formae in quo I illius formae in quo $\mathrm{V}$

ita non contingit dare ultimum gradum $\mid$ ut non contingit dare ultimum gradus $\mathrm{C}$

caliditas ultimo est $\mid$ caliditas est ultimo E, est caliditas ultimo $M$ sed sicut terminatur I sicut terminatur $\mathrm{E}$, si sic terminatur $\mathrm{C}$ nec remissio in qualitatibus $\mathrm{I}$ nec remissio in qualibus $\mathrm{V}$ vel etiam intensio I vel etiam intentio $\mathrm{V}$ 
quod aliquid posset $\mathrm{I}$ quod aliquid possit $\mathrm{M}$

aliquod ultimum in quo est $\mid$ ultimum aliquod in quo est $M$

[3.7.3]

Concessum enim est I Concessum est $\mathrm{M}$

quod ignis possit $\mathrm{I}$ quod ignis posset $\mathrm{EV}$

[3.7.4]

scilicet calidissimus, vel potest $\mid$ scilicet calidissimum vel potest

$\mathrm{CV}$, scilicet calidissimus potest $\mathrm{M}$

propriae naturae non admixtum $\mid$ propriae naturae admixtum $\mathrm{CE}$,

a add. E

in medio sphaerae suae $\mid$ in medio suae sphaerae $M$

sic ignis bene potest $\mathrm{I}$ sic ignis potest bene $\mathrm{V}$

et quantum est ex $\mathrm{I}$ in quantum est ex $\mathrm{E}$

ex se illum | ex se istum $M$

gradum sibi determinat I gradum sibi determinet $\mathrm{C}$

tamen nec sub gradu I nec tamen sub gradu $\mathrm{V}$

quem potest habere a $\mathrm{I}$ quod potest habere ac, quem potest habere

patiendo a EV

sit naturaliter frigida | sit frigida naturaliter $\mathrm{M}$

esse calidiorem aere I esse calidiorem aeris C

[3.8.1]

Ad ultimam rationem | Ad ultimum $M$

non est eadem causa I non est causa eadem $M$

gradus mutatio continua I continua corr. ex continue C se tenet ex parte I pendet ex parte $\mathrm{V}$

quamvis non sit dare primum mutatum $\mid$ cum non sit dare primum mutatum $\mathrm{M}$, quamvis non sit dare mutatum $\mathrm{E}$ potentia, contingit tamen dare primum mutatum esse in om. hom. E

contingit tamen dare $\mid$ contingit dare tamen $M$

Nam ille gradus manens idem | Nam iste gradus manens idem

$\mathrm{MV}$, Nam ille gradus idem manens $\mathrm{E}$

non mutatur, sed quaecumque $\mid$ non movetur sed quaecumque $M$ tollit illum gradum $\mid$ tollit corr. interl. ex intelligit $M$ et habet istum pro illum

et ideo corruptio I et non corruptio C 
illius gradus non I istius gradus non $M$

per aliquid incompossibile I per aliquod incompossibile $V$, per aliquid per imcompossibile $\mathrm{E}$

quod sit primus terminus illius $\mid$ qui sit primus terminus illius $C E$, qui sit terminus primus istius $M$

inductum esse $\mid$ inductum est $\mathrm{E}$

ante quemcumque gradum $\mid$ ante quemcumque $\mathrm{E}$

[3.8.2]

Adhuc posset $\mid$ Ad hoc posset $M$

quod non est dare $\mathrm{I}$ non est dare $\mathrm{V}$ (fortasse recte)

absque distinctione $\mid$ absque determinatione $M$

non est dare ultimum $\mid$ est dare ultimum CEV, non (suppl. mg)

est ultimum dare $M$

[3.8.3]

Philosophus nec illam I Philosophus nec istam M movet nec eam ... scilicet in igne om. CE

movet nec eam I movet nec ipsam $M$

fieri in generabilibus et corruptibilibus $\mid$ fieri in generationibus et corruptionibus $\mathrm{M}$

in igne et aere $\mathrm{I}$ in igne et aeris CE

et talibus formis ... dare ultimum non esse om. V

terminatur ad generationem $\mid$ terminatur ad aggregationem $\mathrm{C}$

generationem esse alterius $\mid$ generationem alterius $\mathrm{E}$

est universaliter verum I universaliter verum $E$

dare primum posterioris I dare posterioris $\mathrm{V}$

\section{PASSAGES FROM BURLEY}

I add here a listing of passages from Burley's De instanti that are found in Wylton's question. The citations to page and line numbers following each quotation from Burley refer to the edition of De instanti by $\mathrm{H}$. and C. Shapiro in "De primo et ultimo instanti des Walter Burley," Archiv für Geschichte der Philosophie 47 (1965): 159_ 173. Since this edition of Burley's De instanti is rather unreliable, I have on several points consulted the Città del Vaticano, Biblioteca Apostolica, MS. Vat. lat. 4545. 
For [1.1] Ed adhuc confirmatur sic: omne quod est in tempore est in instanti, ita quod non est in tempore nisi quia in instanti; ergo si habet esse finitum, habet aliquod instans ultimum in quo ultimo habet esse, quia, ex quo habet esse finitum, habet aliquam mensuram in qua finitur suum esse, et ista mensura non est tempus nisi quia instans est; ergo habet instans in quo finitur suum esse, et necessario est ultimum instans sui esse; sed res permanens non habet esse in tempore nisi quia in instanti; ergo est dare ultimum instans in quo res permanens habet esse. (Shapiro 163.35-42)

For [1.2] Arguo septimo ad secundam conclusionem sic: cuiuslibet finiti, ex ea parte qua finitum est, est dare terminum intrinsecum ipsum terminantem, quia aliter non esset finitum ex illa parte; sed esse durativum Sortis est quoddam finitum etiam ex parte post; igitur ex parte post habet terminum intrinsecum ipsum terminantem; ergo est dare ultimum esse Sortis, quia tempus ipsius durativi esse est finitum tam ex parte post quam ex parte ante. Igitur qua ratione est dare terminum intrinsecum ex parte ante, eadem ratione est dare terminum intrinsecum a parte post. Si igitur est dare primum esse Sortis, ita est dare ultimum esse Sortis. (Shapiro 163.11-19)

For [1.3] Tertio probatur quod est dare ultimum instans in quo res permanens habet esse. Probo sic: si non esset dare ultimum instans rei permanentis, semper duraret; consequens est impossibile; ergo illud ex quo sequitur. Consequentiam probo sic, quia, si non esset dare ultimum instans in quo Sortes habet esse, tunc sequitur "Sortes in hoc instanti est; igitur in aliquo alio instanti erit," quia cum hoc instans non sit ultimum esse Sortis nec esse possit, oportet, si sit in hoc instanti, quod sit adhuc in alio. Et adveniente illo alio instanti, cum illud non sit ultimum, oportet quod sit post illud instans in aliquo alio, et cum illud aliud non sit ultimum, oportet dare quod adhuc sit in alio, et sic semper. Ergo, si non est dare ultimum instans in quo Sortes habet esse, sequitur quod Sortes semper erit. Et sicut est de Sorte, ita est de quolibet alio conceptu permanente. (Shapiro 160.33-44)

For [1.4] Nono probatur consequentia sic: non currere est res permanens, et tamen contingit dare ultimum instans non cursus. Nam in primo instanti temporis mensurantis cursum non est cursus, tunc non cursus est ultimum; ergo est dare ultimum instans rei permanentis. (Shapiro 163.43-164.2) 
For [1.5] Sexto ad eandem conclusionem, Aristoteles, VI Physicorum, arguit sic: si motus esset in instanti, ergo in quolibet instanti [instanti scripsi, spatio MS.] et per consequens in ultimo. Eodem modo ego arguo formaliter: forma permanens est nata esse in instanti; ergo in quolibet instanti, et per consequens in ultimo, vel ratio Philosophi [ideo] non valet ibi. (Shapiro 163.20-24)

For [1.7.1] Secundo probatur eadem conclusio sic: ponatur quod aliquid quiescat in gradu caloris vel caliditatis perfectissimo per totum tempus ac, et in instanti $c$ sit primo illud approximatum summo frigido in illa proportione in qua hoc sit natum agere et illud pati. Isto casu posito, certum est quod in $c$ est calidissimum, et numquam post $c$ est calidissimum. Et quod in $c$ est calidissimum apparet, quia continue prius fuit calidissimum, et in $c$ non est actio, quia actio non est in instanti; ergo adhuc remanet calidissimum in $c$. Et quod numquam post $c$ erit calidissimum probo, quia, si sic, sequitur quod agens esset approximatum passo per tempus in quo hoc natum est agere et illud pati, et tamen nec hoc ageret nec illud pateretur, quod est impossibile. Et [quod] sequitur hoc quod agens approximatum passo per tempus in quo hoc natum est agere et tamen nec hoc ageret nec illud pateretur, si post $c$ remanet calidissimum, probo, quia, si frigidissimum ageret in isto tempore, cum sua actio fiat continue removendo caliditatem in passo, oporteret dicere quod caliditas in passo remitteretur, quia si non remitteretur, sed maneret [sub] eodem gradu nunc ut prius, sequitur quod quiesceret, et tunc simul quiesceret et moveretur. (Shapiro 161.1-17)

For [1.7.2] Huic rationi forte diceretur quod est dare ultimum instans in quo aliquid est calidissimum. (Shapiro 161.18-19)

For [1.7.3] Contra, probo quod non sit dare ultimum instans in quo forma sit sub gradu intensissimo. Nam per Philosophum, V Physicorum, omne quod prius est non ens et postea ens oportet quod aliquando fiat ens. Aliam etiam probationem ponit Philosophus, quod, cum aliquid fit, non est. Ex his arguo sic: si post illud instans in quo tu dicis ultimum esse in quo hoc est calidissimum fiat non calidissimum, oporteret fieri per aliquod medium. Certum est enim quod non fit non calidissimum in instanti in quo est hoc calidissimum, cum sic mutari non possit in instanti; nec etiam sic fit non calidissimum quando erit iam non calidissimum; ergo in aliquo tempore fit non 
calidissimum; sed quod fit non est; ergo in illo tempore medio non est nisi calidissimum. Ex quo sequitur quod datum esse ultimum non est ultimum, cum post illud instans adhuc maneat calidissimum. Similiter cum arguitur de isto ultimo dato, ita argui potest de quolibet ultimo in infinitum, et per consequens impossibile est dare ultimum instans in quo est calidissimum. (Shapiro 161.19-33)

For [1.7.4] Item, probo quod, si est dare ultimum gradum, etiam est dare ultimum formae [formae scripsi, formale MS.] absolutae, scilicet ultimum in quo aliquid est calidum. Nam sicut est dare aliquem gradum maximum caloris secundum quem aliquid est calidissimum, ita est dare aliquem remissum secundum quem aliquid est [remissum] imperfectissimum [forte pro: imperfectissimae] caliditatis. Nam sicut in formis naturalibus est dare maximum, ita et minimum. Pono ergo quod aliquid quiescat per totum $a$ tempus sub isto gradu caloris maxime remisso et quod in instanti $c$ sit primo sibi approximatum corpus frigidum. Tunc quaero: aut illud corpus remississime calidum post $c$ erit sub isto gradu caloris aut non. Si detur quod sic, sequitur, ut prius dictum est, quod, agens approximatum passo in debita proportione et in debita mensura nec hoc agit, nec illud patitur, quod est inconveniens. Si detur aliud membrum, quod numquam post $c$ est sub isto gradu, nec sub gradu perfectionis caloris, et per consequens in $c$ est sub ultimo calore, quia calor non potest esse sine aliquo gradu caloris; igitur $c$ est ultimum [instans] in quo calor est in isto subiecto, et sic, si sit dare ultimum in gradibus, erit dare ultimum instans formae absolutae. (Shapiro 161.34-162.5)

For [2.1] Si autem loquamur de re permanente durante per tempus, dico quod per talem rem possum duo intelligere, scilicet vel formam positivam tantum, cuius [esse] existit totum simul in tempore, vel formam indifferentem ad formam positivam vel privativam, dummodo talis sit quod duret per tempus et habeat omnes suas partes simul vel ei [ei scripsi, enim MS.] non repugnet omnes suas partes habere simul. Exemplum secundi: non albedo vel non album est forma privativa habens [esse] totum [totum scripsi, tota MS.] simul durans per tempus.

$\mathrm{Si}$ autem loquamur de forma permanente positiva durante per tempus, in esse et conservari non dependente a re successiva, adhuc haec est duplex, quia vel ista forma habet latitudinem in gradibus ita quod, corrupto suo gradu, potest forma remanere eadem simul sub alio gradu, vel ista forma importat talem perfectionem secundum 
gradum punctualem. Exemplum primi: sicut albedo, nigredo, caliditas, frigiditas, ignis, aer, aqua. Omnia ista habent latitudinem in gradibus. Accidentia enim praedicta et consimilia habent latitudinem per se graduum; sed substantiae, ut ignis, aer et huiusmodi, habent latitudinem graduum per accidens. Unde communiter accidentia et omnia ista sub tota latitudine possunt salvari. Exemplum secundi: in motu locali ubi in hoc instanti signato in quo mobile est in primo instanti motus vel in medio. Consimiliter, bicubitum, tricubitum in motu augmenti. Similiter, calidissimum, frigidissimum et omnis huiusmodi gradus alterationis. (Shapiro 165.16-36)

For [2.2] $\mathrm{Si}$ autem loquimur de re permanente positiva cuius perfectio habet latitudinem graduum, dico quod non est dare ultimum instans in quo talis res habet esse. Et in talibus rebus habet intelligi processus Philosophi VIII Physicorum. (Shapiro 170.36-39)

For [2.3] Unde breviter in talibus formis habentibus latitudinem graduum, quando corrumpuntur per alterationem, non est dare ultimum instans esse talis formae, quia, si aliquis daret instans ultimum in quo est forma prior, cum illud sit tunc instans ultimum formae prioris et primum esse posterioris, aliter non esset tempus continuum, et tunc necesse esset concedere vel quod aliquid, quando factum est, non esset, vel quod aliquid simul esset et non esset, quorum utrumque est impossibile totaliter. Et causa huius est quia in transmutatione talis formae mutatio continua cadit supra priorem formam, quae mutatio terminatur ad mutatum esse illius formae, quod est eius corruptivum et inductivum formae contrariae, et per consequens forma prior in illo instanti non est cum sua corruptione, cum corrupta sit; et ideo necesse est dare in talibus quod in illo instanti, ultimo scilicet [forte pro: secundum] subiectum, res denominetur a posteriori passione, ut dicit Philosophus. (Shapiro 171.28-42)

For [2.4] See Shapiro 165.36-40 and 169.40-170.35.

For [2.5] at "Si per rem permanentem. . . ." See Shapiro 165.41-43 and $172.1-10$.

For [2.5.] at "Si loquamur de negatione. . . ." See Shapiro 165.43166.5 .

For [2.5] at "Si primo modo numquam" See Shapiro 172.11-20. 